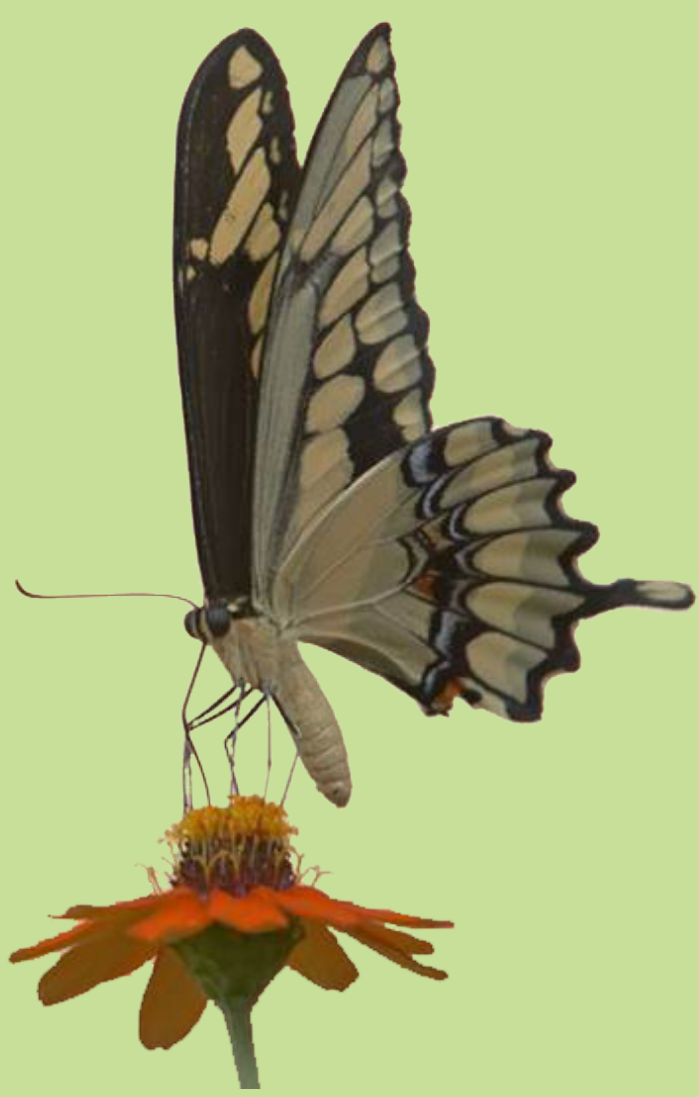

\title{
Ecologies of Innovation
}

Verena WINIWARTER (Ed.)

KIOES Opinions 6 (2017)

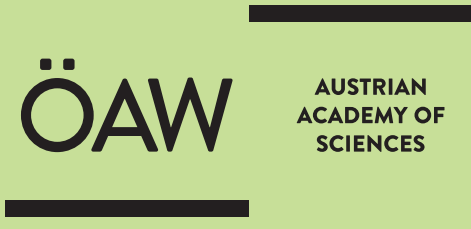


KIOES Opinions 6 (2017): 1-39.

doi: 10.1553/KIOESOP_006

Imprint:

KIOES Opinions are published by the Commission for Interdisciplinary Ecological Studies (KIOES) of the Austrian Academy of Sciences (OeAW). KIOES publishes current opinions written, initiated or invited by KIOES related to topical subjects on an irregular basis in KIOES Opinions. The target audience includes scientists, policy makers and the public. Opinions expressed in this article are solely those of the author(s), and they do not necessarily reflect in any way those of KIOES or OeAW.

More information about KIOES and download of KIOES Opinions at http://www.oeaw.ac.at/kioes

Managing Editor:

Viktor J. Bruckman

Layout: Karin Windsteig

Cover photo credit: Fotofolia

Title page credit: Verena Winiwarter

"Mosses overgrow an abandoned orchard terrace wall." Wachau, Austria, 2016.

Editorial office:

Commission for Interdisciplinary Ecological Studies, OeAW, Dr. Ignaz Seipel-Platz 2, 1010 Vienna

E-mail: viktor.bruckman@oeaw.ac.at, +431515813200 
Table of Contents

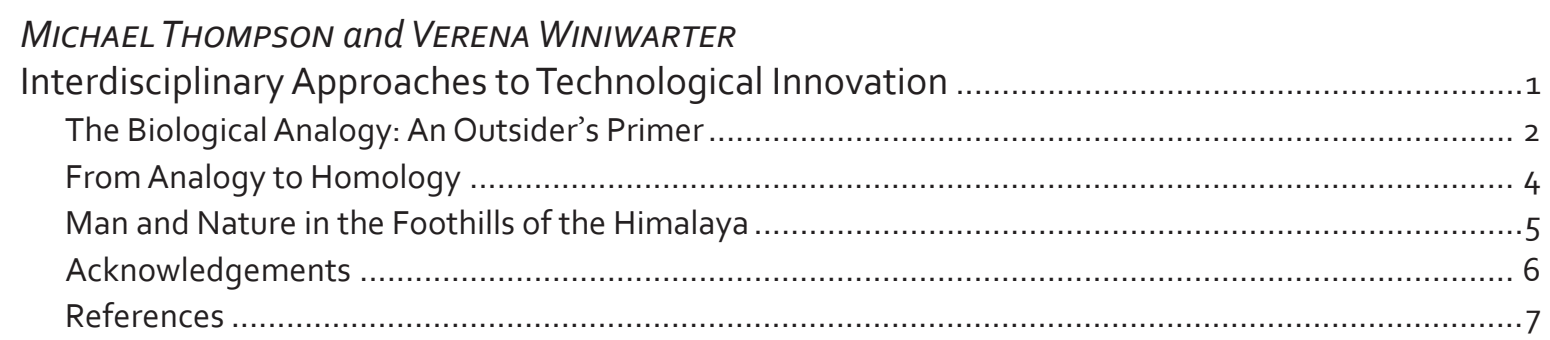

\section{MICHAEL THOMPSON}

The Wheels on the Bus Go Round and Round

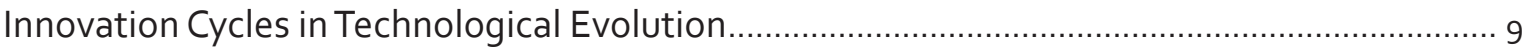

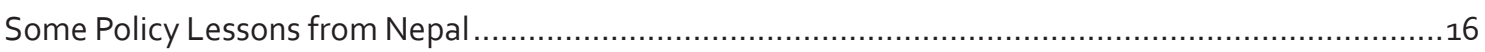

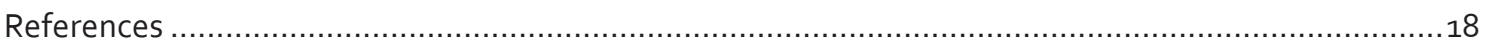

VERENA WinIWARTER, GeRTRUd HAIDVOGL and Stefano Brumat

Co-creative Innovation for Sustainability: Creating Robustness in a Rapidly

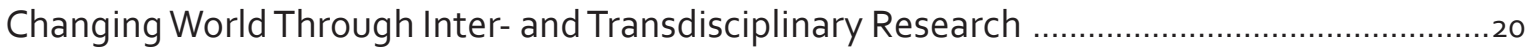

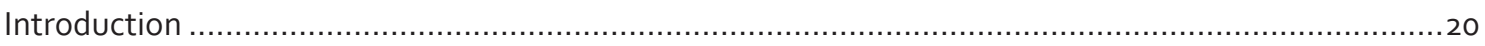

Humanities and Social Sciences are necessary for Sustainable Development..................................22

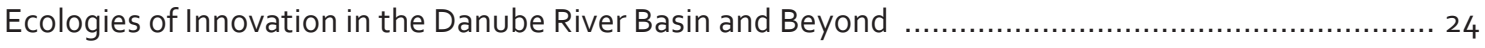

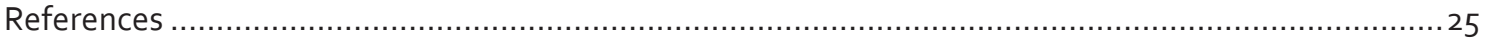

BRIAN D. FATH

Understanding Ecosystem Dynamics for Designing Socio-Economic Systems:

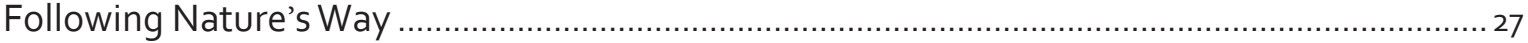

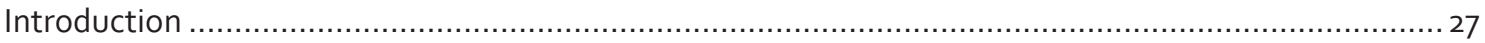

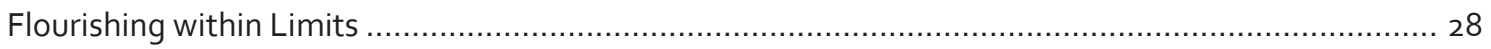

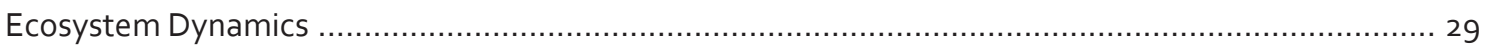

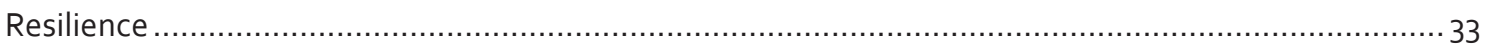

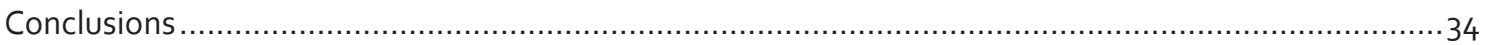

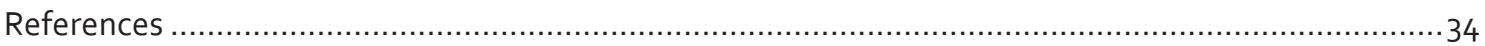

HARALD KATZMAIR

Summary - The Cycle of Innovation and its Ecology

On Entrepreneurs, Bureaucrats and Fatalists and Their Role in the Process

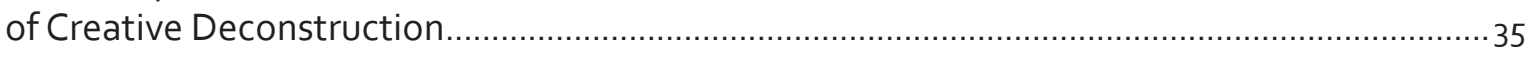

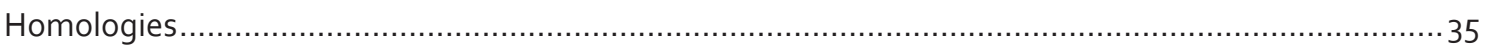

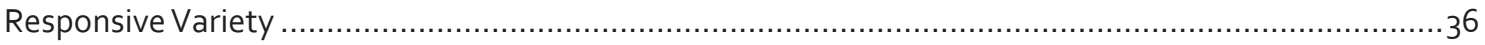

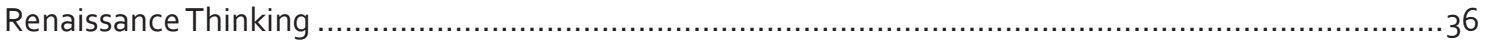

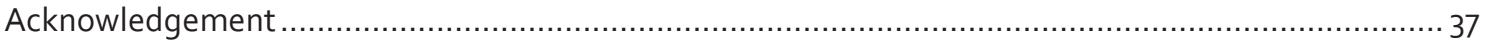

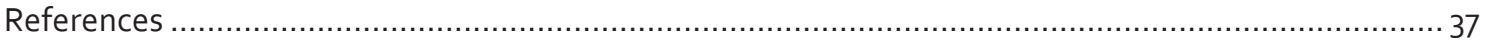

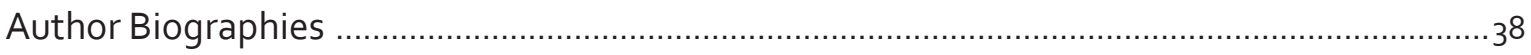




\title{
Interdisciplinary Approaches to Technological Innovation
}

\author{
Michael Thompson and Verena WiniWARTER ${ }^{1}$
}

When Harald Katzmair invited a group of people to join a breakout group discussion at Austria's Top Level Forum for Science-Policy Dialogue, the Forum's Alpbach's Technology Talks in 2016, he formulated the scope of the session as follows:

... to discuss a generalized model of knowledge (including its different cultures of "searching for solutions") that should inhabit an innovation ecology in order to be successful. Based on this discussion the session also should address the practical questions of new frameworks and policy measures that are required to strengthen the responsive variety (resilience) of our innovation system.

The session was designed to shed light from different angles at the question "how the horizontal connectedness of an innovation system, the collaboration across different modes of knowing could be strengthened", if that were the goal. To address this issue, Harald Katzmair asked participants to think about non-traditional questions, e.g. about: "The specific role of charitable foundations to fund crossscale-science but also the need for special governmental programs or institutional manifestations to strengthen the field of open innovation and citizen/ community science." All contributors were offered two questions to concentrate their thoughts:

- How can we learn in a systemic way from history the vital lessons we need to bear tribute to in future innovations and then harness those lessons for innovation processes?

- What lessons can we extract from the examples of environmental history and related fields of research on how an innovation cycle can benefit from collaboration across different regimes?

The session was based on the concept of the cycle of "creative destruction", as first formulated by eminent economist Joseph Schumpeter. By bringing in Resilience Science, Cultural Theory and a longterm, open-science-based perspective on Sustainable Innovation, light should be shed on different stages of the innovation cycle, as they require different "characters": scientists, entrepreneurs, visionaries, etc. Harald Katzmair brought these different actors into play, because, as the session abstract formulated:

"computational science shows that these different characters apply different search strategies to solving problems. Citizen and Community Science as a broker within this ecology of innovation has a special (practical) role."

It turned out that three of the participants were affiliated in various ways with IIASA, the International Institute for Applied Systems Analysis in Laxenburg, Austria during the following year, 2017. Harald Katzmair in the meantime had untiringly organised the $5^{\text {th }}$ Viennese Talks on Resilience and Networks "Resilience of Place: Networking in an age of division", which took place at Wirtschaftsuniversität Wien hosted by their Competence Centre for Sustainable Development (Dr. Fred Luks). And, alas, the three authors of this volume met again there. This fortunate opportunity to continue the conversation that had started in Alpbach led to the volume you, dear reader, are now holding in your hands or, more likely, displaying on your screen.

1 The authors are listed in alphabetical order, and contributed equally to this paper. 
As we assume an interdisciplinary readership for KIOES Opinions, the following paragraphs give a very quick overview of the concept "Ecologies of Innovation", and of the criticisms of that concept, designed for the non-specialist. None of the three authors of this volume considers him or herself a specialist in this field. This is exactly why we found it worth collecting our contributions based on the Alpbach presentations, offering fresh perspectives "from a distance".

\section{The biological analogy: An outsider's primer}

The obvious place to start, it might seem - given our explicit focus on innovation, resilience and systems is with the innovation systems theorists who, over the past three or so decades have frequently invoked the concept of "ecologies of innovation". In the late 1980s, for instance, William Barnett used analogies (such as mutualism) in his efforts to explain the development of a "systematic technology": the US telephone system (Barnett, 1990). This sort of appeal to insights from ecology seems reasonable enough when one considers the evolutionary nature (in the sense of "one thing leading to another") of human cultural production. Indeed, the Cultural Evolution Society holds that:

Every new technology builds on what came before, filling niches based on user needs and evolving into "adjacent possibles" through the processes of cultural transmission and social learning. Or, said more succinctly - technology evolves. Thus it can be studied using the tools of evolutionary biology (Cultural Evolution Society, 2017).

While the fate of organisations, in fields as different as history and economics, has long tended to be attributed to human agency (that of leaders and entrepreneurs, in particular), structural approaches, among them the ecological one, focus on contextual causes that are seen as influencing "opportunity structures" and "resource constraints" (Baum and Amburgey, 2000 , p. 3). The perspective thus shifts from studying the organisation itself to studying its relations to its environment. That environment, of course, changes, with the bounded rationalities and structural inertias of the organisation's constituent individuals then making it increasingly difficult to keep the organisation itself aligned with the environmental demands. The result, they argue drawing the analogy with the lifecycle of individual organisms, is an ever-growing risk of senescence. However, we should note that some eminent organisation theorists - notably Emery and Trist (1965) and Fairtlough (2005) - have taken the systems/contextual approach without any recourse to ecological or biological analogy: something that we will return to in more detail in our next section.

The senescence/life-cycle analogy does seem to fit many organisations (though some - Unilever, for example, which has succeeded in getting product lifecycles to go round inside it rather than being carried along with them - seem to renew themselves as they get older, and much the same seems to hold for the even longer-lived Roman Catholic Church). The oftinvoked analogy with ecological niches also seems to fit, with inter-organisational competition, the intensity of which can and does vary, being interpreted as a force leading to niche-change. Micro-breweries, for instance, flourish as they together open up a niche in which they are more or less immune to competition from the big boys, many of whom are intent on swallowing up their equally massive rivals. Indeed, nicheformation is pretty much at the heart of the whole "ecology of innovation" notion, with Goldstein et al. (2010, p. 8) stressing that "in an important sense, an ecosystem is the most accurate picture of what a complex, non-linear, adaptive and interactive system is all about". "Every organisation", they continue, "occupies a niche within its communities, customers, suppliers, strategic partners and competitors, and this places constraints on the organisation's choices". With "information being discovered all the time, by many people in many specific situations", successful adaptation hinges on differentiating between the noise created by all these interactions and the signals of imminent change within this stream.

But is it possible for organisations to differentiate between noise and signal? There is certainly very little evidence of this happening in relation to that recent, and rather emphatic, "imminent change": the 2007/8 global financial crisis. Indeed, the British Queen put her finger on precisely that when, having listened to the assembled luminaries at the London School of Economics explaining what had happened, she asked: "Why did no one see this coming?" And the trouble is further compounded when we recognise, as we must, that one man's noise is another man's signal: that "contradictory certainties" spring eternal 
(Thompson and Wildavsky, 1986; Huang et al., 2014). Moreover, if organisations could successfully adapt to the imminent changes they could see coming, then Schumpeter's "creative destruction" would be a non-starter!

This imperative to distinguish between noise and signal - so manifestly unachievable in the case of the global financial crisis - is now central to the WBGU's (the German Advisory Council for Global Change) proposal for the establishment of a new scientific discipline - "transformation research" - which would specifically address transformation processes; that towards a sustainable low-carbon society being a prime exemplar (Nakicenovic and Schulz, 2011). "Is it noise or is it signal?", we sceptics would observe, is probably an unanswerable question (compounded by the need to ask "Whose noise and whose signal?"), as too is the question "Is it change or is it transformation?". Moreover, we might also point out, we often get transformations - Schumpeterian "gales of destruction", such as those that punctuate the 50-odd-year economic cycles known as Kondratieff waves - in the absence of anything resembling "transformation research" (Mars and Thompson, 2013). All of which suggests that there is something not entirely right with the concept of "innovation ecologies". The trouble stems, it has been argued, from an over-reliance on analogy:

... biological concepts such as ecology and/or ecosystem fail to capture the complexity of socially dynamic environment (sic) of knowledge and innovation. Therefore, biological metaphors like "knowledge ecology" and/or "innovation ecosystem" provide abstract and simplistic explanations of economic and social evolution as a harmonious process of natural selection (Papaioannou et al., 2007, p. 25).

Worse still, we would add, these analogy-based arguments often ride roughshod over the disciplines ecology and biology - from which they are borrowed.

- Even in conventional ecology, there are two kinds of ecosystem - usually referred to as the "pioneer community" (characterised by the generalised and fast-breeding "r-selected species") and the "climax community" (characterised by the specialised and slow-breeding "K-selected species") - and in C.S. ("Buzz") Holling's "ecocycle" critique of that orthodoxy things, rather than just transitioning (through the process of succession) from pioneer to climax, cycle through a total of four "basins of attraction". And only one of those four - the climax community - is characterised by niches (Holling, 1986). So the proponents of "innovation ecologies" are ignoring three of the four kinds of ecosystem. They can therefore say nothing about resilience, which Holling famously defined as the ability of a system to cycle endlessly through four different basins of attraction (Holling, et al. 1978) ${ }^{2}$. The now currently muchrelied on "bounce-back" definition - the ability of a system to remain within the same basin of attraction (which is the only definition available to those who put it all down to niches) - is what Holling calls brittleness: almost the opposite of resilience (see Box D: "the trouble with bounceback" in Thompson and Beck, 2014, pp. 28-29).

- "Ecology" and "evolution" are being used almost interchangeably by those who are reasoning in terms of analogy. But ecology, while acknowledging that evolutionary processes are always at work, is focused on the interactions of the various species in the here-and-now. Bringing the two together is then a quite formidable challenge: one that is taken up, to some considerable extent, in John Maynard Smith's notion of "evolutionarily stable strategies” (Smith, 1982).

- Whilst biological systems and socio-technical systems both evolve, the ways in which they can and cannot do this vary rather dramatically. There is, for instance, no socio-technical equivalent of speciation. Nor, thanks to speciation, is there any biological equivalent of the convergence that often occurs in socio-technical evolution (telephony, photography, television and computers, for instance, all merging into smart phones). Furthermore, the absence of any genetic basis to technological change enables "reversibilities" that are simply not available in biological systems. Hence the ever-present possibility of re-engineering; a mechanical engineer would be horrified at the way the nerves and arteries in a giraffe's neck are configured.

- Moreover, humans, unlike other animals, have cognition: they both see and know. Karl Marx put

2 This definition is clearly discernible in the section headed "Stability and Resilience of Systems" (Holling, et al., 1978, pp. 9-11). 
this very nicely: "What distinguishes the stupidest of architects from the cleverest bees is that the architect constructs his building in the imagination before he constructs in reality" (Marx, 1967 [1857], p. 178). With humans inevitably doing something - imagining first, then acting that other animals could never do, it would surely be foolish to assume that the tools of evolutionary biology will work just fine for technology too.

So the concept of natural selection, we must conclude, runs into all sorts of difficulties as we go from natural systems to socio-technical ones, as has long been pointed out by leading figures in both the social and biological sciences:

- Jon Elster, in discussing functionalism (which holds that the environment exerts a selective force on human behaviour), concludes that such explanation "has no place in the social sciences, because there is no sociological analogy to the theory of natural selection" (Elster, 1982, p. 463, emphasis added).

- John Maynard Smith (the pioneer of evolutionary game theory) coming from the other side as it were, has reached much the same conclusion:

... the theory [game theory applied to human social behaviour] requires that the value of different outcomes (for example, financial rewards, the risks of death and the pleasures of a clear conscience) be measured on a single scale. In human applications, this measure is provided by "utility" - a somewhat artificial and uncomfortable concept: in biology, Darwinian fitness provides a natural and genuinely one-dimensional scale (Smith, 1982, p. vii).

But surely, many will object, natural selection has to be a valid concept when it comes to the process of technological evolution. After all, they will point out, natural selection is at the very heart of neoclassical economics. Indeed it is. The idea, in the neoclassical view, is that firms and individuals will all the time be coming up with innovations: mutations, you could say. The market then puts those innovations into competition with one another, with that process then quickly revealing the most efficient one: the one with the lowest "unit cost", that is. That innovation will then be adopted by consumers, with the others going to the wall. And it is through this "survival of the fittest" process that we find our technologi- cal way along the best possible evolutionary path.

Well, yes, argues the evolutionary economist Brian Arthur, provided all returns to scale are decreasing. The trouble is that, in the real world, we often encounter increasing returns to scale: situations in which small and random events, early on in the process, can result in a less efficient technology getting that little bit ahead of its rivals, with that apparent success then attracting ever more adopters, thereby causing the more efficient technology to go to the wall: the "Matthew effect", as it is sometimes called (from the biblical "To those that have shall be given and from those that have not shall be taken away, even that which they have"). The result is lock-in: we are stuck with the less efficient technology, and "changes at the margin" - the orthodox economic nostrum - are of no avail. Only if we can deliver what ecologists call an "optimal perturbation" will we be able to jolt ourselves out of the lock-in and be free to find our way to the more efficient rival (Arthur, 1989; Arthur 2009; also see Box F, “Competing technologies under increasing returns to scale" in Thompson and Beck, 2014, pp. 33-35). So technological evolution is not Darwinian: a conclusion that almost got Brian Arthur sacked when first came up with it (at IIASA during the 1980s) but for which he was later awarded the Schumpeter Prize.

\section{From analogy to homology}

All this orthodoxy-challenging work - on ecocycles and resilience, on the one hand, and on increasing returns to scale and lock-in, on the other - took place, during the 1970s and 80s, at IIASA: the former largely by C.S. ("Buzz") Holling; the latter largely by Brian Arthur. In marked contrast to what we have been calling the "innovation ecology approach", the ecological notion of optimal perturbation is not being used analogously when it is applied to technological evolution. Rather, the dynamics of these two systems - one biological, the other socio-technical - are sufficiently similar for them both to require the notion of optimal perturbation in relation to the ways in which they evolve.

Nor is that the end of it. If fourfold ecocycles are vital to biological systems then maybe the same dynamical arrangements are vital to socio-technical systems, and this is precisely what the cultural the- 
ory, pioneered by Mary Douglas (a frequent visitor to IIASA in those days) and by one of us (Michael Thompson), argues. If, as economists and political scientists have long maintained, there are four distinct kinds of goods - private, public, common pool and $c l u b$ - then perhaps each is supportive of a particular "way of organising": markets (i.e. ego-focused networks) hierarchies (bounded and ranked groups), enclaves (bounded but egalitarian groups) and excluded margins (e.g. Marx's Lumpenproletariat). And, since two of those - markets and hierarchies - have long been familiar to social scientists (in the same way that pioneer and climax communities have long been familiar to ecologists) cultural theory's novelty lies in its addition of the other two, and in its making explicit the various "social constructions of reality" Holling called them "myths of nature" - that render rational the very different behaviours of those actors (Harald Katzmair's “different characters", who we introduced on our first page) who are striving to uphold and strengthen these contending ways of organising. Thus it was that, one afternoon in the early 1980s, these two dynamic systems - one biological, one socio-technical - were mapped onto one another, on a flip-board in the coffee room outside IIASA's Wodak Theatre. But where, some will want to know, does this leave Brian Arthur and his seemingly "knife-edge" non-linearity: lock-in?

One of us (Michael Thompson) brought up this question with Brian Arthur, over a few beers, pointing out that the Soviet Union (as then was) was not locked into its ubiquitous apartment-block technology (rather than that of, say, terraced houses) because some butterfly over there in Siberia happened to flap its wings. Rather, there were pre-existing institutional commitments that assured that the former technology was adopted and that the latter never saw the light of day. Those commitments, Michael Thompson argued, were of the hierarchical kind - the top-down and standardized provision of housing as a public good - and so he was delighted, some years later to come across a photograph of President Khrushchev gleefully playing with a model, complete with cranes to lift the concrete panels off the specially designed trucks and into their allotted slots, of one of these industrialised building systems (see Zinsmeister, 2002, p. 58). Brian agreed that this was so, but explained that, in his work, he was concerned simply to show that, contra the founding assumptions of neoclassical economics, lock-in will happen even in the absence of any pre-existing institutional commitments. That, he explained, was the crucial justification for the shift from neoclassical economics to evolutionary (i.e. Schumpeterian) economics.

So we are not there yet. We still need to put the institutional into evolutionary economics, and that, you could say, is what we are seeking to do in this collection of papers. Our focus therefore, is on the dynamics of these systems, be they biological or socio-technical, and not on their substance. If they turn out to be essentially the same - fourfold, selforganising, self-disorganising, self re-organising and so on - then we are dealing with homology not analogy. And, since cyclicity is one of the properties they have in common, we have elected to focus on what we call "innovation cycles" in our efforts to make some sense of those two systems' interaction: man and nature, you could say, as a single but complex system (Thompson, 2002). So let us finish with a little "worked example" of that kind of interaction: an institutional evolutionary economics take on the processes that drive technological change (and, as we will see, not always for the better).

\section{Man and nature in the foothills of the Himalaya $^{3}$}

For centuries, Nepali farmers on the "inland delta" that has been formed by the Tinau River releasing its silt as it debouches onto the Gangetic Plain were able to grow two, or even three, crops of rice a year: one during the monsoon period, when the river itself flooded their fields; the other during the dry season when the river, unassisted, could not do what was needed. So the farmers, as the dry season got under way, built dams out of brushwood and clay that raised the river a metre or so: sufficient for the water to be diverted onto their fields, and robust enough to last until the next monsoon, when the dams, no longer needed, were swept away. This simple but effective technology had to be a community effort, since it required the pooled and skilled labour of a quite large group of farmers. Their socio-technical system,

3 Parts of this final section are borrowed (with some small changes) from Beck et al. (2018). 
in other words, shaped up the water as a commonpool good.

These dams, which proliferated in a cascade fashion across the entire inland delta, were done away with by the Hattisunde Barrage: a massive international aid-funded concrete structure that almost immediately became a "development tomb" (bikasey chihan in Nepali) when the river changed its course: that being what Himalayan rivers do, once they reach the plains. So, in Rumsfeld-speak, it was an "unknown known": unknown to the aid providers, known to nearly everyone else. This hierarchically bestowed and large-scale technology, for the short time it lasted, reshaped the water as a public good while, at the same time, making a return to the egalitarian and smallscale technology well-nigh impossible, thanks to the grid of concrete canals that had been superimposed on the pattern of natural drainage downstream from the barrage.

With the hierarchical solution no longer working, and with the previous egalitarian solution no longer an option, the farmers resorted to the newlyavailable individualistic technology - boreholes and diesel-powered pumps - each cheaply and cheerfully installed on an individually-owned plot: water as a private good. This switch to the individualistic technology has now caught on across much of South Asia - there are estimated to be more than 30 million in India alone - and in many places it has led to a "beggarmy-neighbour" lowering of the water table, with the water becoming a club good as it is captured by those farmers who have the resources, and the ruthlessness, to drill down further: "competitive deepening", as it is called. Those whose wells run dry, because they are no longer deep enough, then find themselves squeezed out into fatalism: a world that is characterised by a sheer lack of options: a world in which, when one door shuts another door closes.

This quick analysis in terms of institutional evolutionary economics reveals that this abysmal state of affairs, down there on the Tinau, has been caused by one particular set of globalizing actors: the World Bank, bilateral aid agencies, UNEP (United Nations Environment Programme) and so on, together with their scientific experts: the IPCC (Intergovernmental Panel on Climate Change), university departments of development studies, a host of global change thinktanks with their "eagle's eye science" and their uncritical reliance on global-level computer models and, we should add (since they are very much out of the same institutional stable) those who are eager to establish that new scientific discipline: transformation research. "With experts like that", many will be inclined to say, "bring on the ignoramuses". And that, of course, is what the Brexiteers and Trump-supporters have now said!

This is not a new idea. Barbara Ward and René Dubos, in their volume accompanying the 1972 conference on the environment, the first held under the UN banner, wrote:

"Since policies concerning the human environment require both social judgement and specialized scientific knowledge, perceptive and informed laymen can often contribute as much as technical experts to their formulation. In certain cases, indeed, laymen may be wiser judges than experts because their overall view of the complexity of human and environmental problems is not distorted by the parochialism which commonly results from technical specialization" (Ward and Dubos, 1972, p. xvii).

The lesson, however, is not that we should leave it all to the ignoramuses but simply that good intentions - after all, those who march under the banner of sustainable development are not intent on world domination - are not enough; they need to be buttressed by hard-thinking. And the switch from neoclassical economics (with its invalid "natural selection" model of technological change) to institutional evolutionary economics (with its "creative destruction-bestowing innovation cycles" and its endless contention between "pre-existing institutional commitments") is a step in that hard-thinking direction.

\section{Acknowledgements}

Verena Winiwarter's role as Chairperson of the Austrian Academy of Sciences' Commission of Interdisciplinary Ecological Studies while at the same time spending her Sabbatical at IIASA's RISK and RESILIENCE program made it possible to publish three pieces that originated from the Alpbach presentations together in this volume. She would like to acknowledge especially the support of IIASA Director Prof. Pavel Kabat and the kindness and welcoming attitude of Dr. JoAnne Bayer, Head of the Risk and Resilience Program. The library services at IIASA are 
outstanding, and allow for the pursuit of research into new fields very efficiently. Michaela Rossini and Natasha Ovtchinnikova, the dedicated librarians of IIASA are most gratefully acknowledged. They will recognize their contributions to the reference list.

We thank the Austrian Federal Ministry of Science, Research and Economy (BMWFW) and the Austrian Ministry for Transport, Innovation and Technology (BMVIT) for enabling this fruitful exchange and in particular Dr. Harald Mahrer, Federal Minister of Science, Research and Economy for his interest in the topic. We would also like to acknowledge the contributions other presenters and participants made to the discussions in Alpbach and Vienna, and we express our gratitude to Dr. Viktor Bruckman and Mrs. Karin Windsteig of the Commission for Interdisciplinary Ecological Studies for their support in creating a publication.

\section{References}

Arthur, W.B. "Competing technologies, increasing returns and lock-in by historical events: the dynamics of allocation under increasing returns", Economic Journal, 99, 116-131, 1989.

Arthur, W.B. "The Nature of Technology: What It Is and How It Evolves". London: Penguin Books, 2009.

Barnett, W.P. "The organizational ecology of a technological system", Administrative Science Quarterly, 31-60, 1990.

Baum, J.A.C. and Amburgey, T.L. "Organizational Ecology”, In Baum J.A.C. (ed) Companion to Organizations. Oxford, UK: Blackwell, 304-326, 2002.

Beck, M.B., Gyawali, D. and Thompson, M. "Chains without ends", In T. Allen and B.C. Bromwich (eds) Handbook of Food, Water and Society. Oxford: Oxford University Press, 2018.

Cultural Evolution Society [Online], https://culturalevolutionsociety.org/index.html, 2017 (Accessed August 16, 2017).

Elster, J. "Marxism, functionalism and game theory: the case for methodological individualism", Theory and Society, 11(4), 453-482, 1982.
Emery, F. and Trist, E. “The causal texture of organisational environments", Human Relations 1965/18.

Fairtlough, G. "The Three Way of Getting Things Done”. Axminster: Triarchy Press, 2005.

Goldstein, J., Hazy, J. and Lichtenstein, B. "Complexity and the nexus of leadership: Leveraging nonlinear science to create ecologies of innovation". New York: Palgrave Macmillan, 2010.

Holling, C.S. (ed), Bazykin, A., Bunnell, P. et al. "Adaptive Environmental Assessment and Management", International Series on Applied Systems Analysis. Chichester, New York, Brisbane: John Wiley \& Sons, 1978.

Holling, C.S. “The resilience of terrestrial ecosystems: local surprise and global change", In W.C. Clark and R.E. Munn (eds), Sustainable Development of the Biosphere. Cambridge: Cambridge University Press, 292-320, 1986.

Huang, L., Ingram, D., Terry, T. and Thompson, M. "Uncertain times, plural rationalities and the pension fiduciary", In J.P. Hawley, A.G.F. Hoepner, K.L. Johnson, J. Sandberg and E.J. Waitzer (eds), Cambridge Handbook of Institutional Investment and Fiduciary Duty. Cambridge: Cambridge University Press, 2014, 265-276.

Mars, G. and Thompson, M. "Individualism versus hierarchy: Kondratieff and his crime waves: the behavioural underpinnings of booms and slumps", In G. Mars, Locating Deviance: Crime, Change and Organisations. Farnham: Ashgate, 149-176, 2013.

Marx, K. “Capital, Vol 1” (English translation). New York: International Publishers, 1967 [1857].

Nakicenovic, N. and N.B. Schulz "World in Transition-A Social Contract for Sustainability", Flagship Report 2011, WBGU, Berlin, Germany, 2011.

Papaioannou, Th., Wield, D. and Chataway, J. "Knowledge ecologies and ecosystems? An empirically grounded reflection on recent developments in innovation systems theory", In The $6^{\text {th }}$ International Triple Helix Conference on University-Government-Industry Relations, 16-18 May 2007, Singapore, 2007. 
Smith, J.M. "Evolution and the Theory of Games". Cambridge: Cambridge University Press, 1982.

Thompson, M. "Man and nature as a single but complex system”, In R.E. Munn (ed) Encyclopedia of Global Environmental Change, Vol. 5. Chichester: John Wiley, 384-393, 2002.

Thompson, M. and Wildavsky, A. "A cultural theory of information bias in organisations", Management Studies, 23(3), 273-286, 1986.

Thompson, M. and Beck, M.B. “Coping with change: urban resilience, sustainability, adaptability and path dependence", Future of Cities Working Paper, London: UK Government Office for Science [Online], http://www.gov.uk/government/publications/future-of-cities-coping-with-change, 2017 (Accessed October 3, 2017).

Ward, B. and Dubos, R. "Only one Earth. The Care and Maintenance of a Small Planet", An unofficial report commissioned by the Secretary-General of the United Nations Conference on the Human Environment, prepared with the assistance of a 152-member committee of corresponding consultants in 58 countries, 1972.

Zinsmeister, A. (ed) "Plattenbau oder Die Kunst, Utopie im Baukasten zu warten”. Hagen: Karl Ernst Osthaus-Museum, 2002. 


\section{The Wheels on the Bus go Round and Round} Innovation Cycles in Technological Evolution

\section{MiCHAEL THOMPSON}

Orthodox social science seldom goes beyond two "ways of organising": markets and hierarchies (in political science), for instance, or market incentives versus social sanctions (in economics) or Gemeinschaft/ Gesellschaft, status/contract, mechanical solidarity/ organic solidarity and so on (in sociology). ${ }^{1}$ Change, in these "two-destination" worlds, is entirely deter- ministic and predictable: being dislodged from one means inevitably ending up in the other. But bump up the number of ways of organising to the full complement - four or five - that is proposed by cultural theor $y^{2}$ and change becomes indeterministic, unpredictable and much more interesting (figure 1).

Fig. 1: Possible transitions in a four or five-destination world (the 8 transitions into and out of autonomy are omitted for the sake of clarity). Source: Thompson (2008), p. 79.

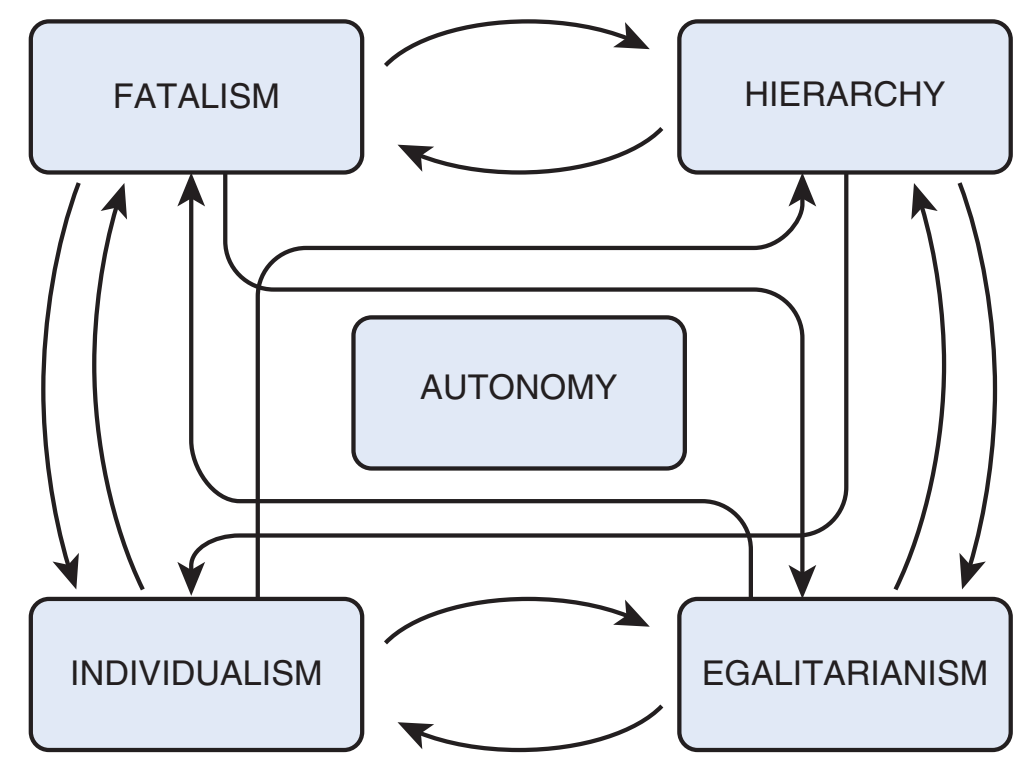

1 These dualisms - how they relate to one another and how, in turn, they relate to the various unitarian, trinitarian and fourfold schemes that are also on offer - are set out in chapter 8 of Thompson (2008).

2 Also sometimes called, inter alia, grid-group theory or the theory of plural rationality (see Douglas, 1978; Grauer et al., 1985; Thompson et al., 1990). 
Here, if you are tipped out of one way of organising you will end up in one of the other three (four if you include autonomy) but you cannot say for certain which one. Then, when you are tipped out of that one, there are three possible destinations (four if you include autonomy) and so on, and on. And, if we then "privilege" a few of those possible transitions, we get the "innovation cycle" that has been sketched by Harald Katzmair:

... an individualist culture of the "doer" at the start-up stage, a hierarchical culture of the stra- tegic manager for growth and scaling, an egalitarian codex to navigate the dramatic turbulences of destruction, an autonomous culture for pioneering and radical innovation, etc., etc. [In the introductory statement for the break-out session - "the cycle of innovation and its ecology" - at the Alpbach Forum, August 26, 2016.]

But I should pause here so as to give a very quick explanation of cultural theory (and from here on, in order to keep a complicated argument a little simpler, I will not include the fifth way: autonomy). ${ }^{3}$

Fig. 2: The four ways of organising (forms of social solidarity) and the myths of nature (convictions as to how the world is and people are) that uphold them. Source: Thompson (2008), p. 21.

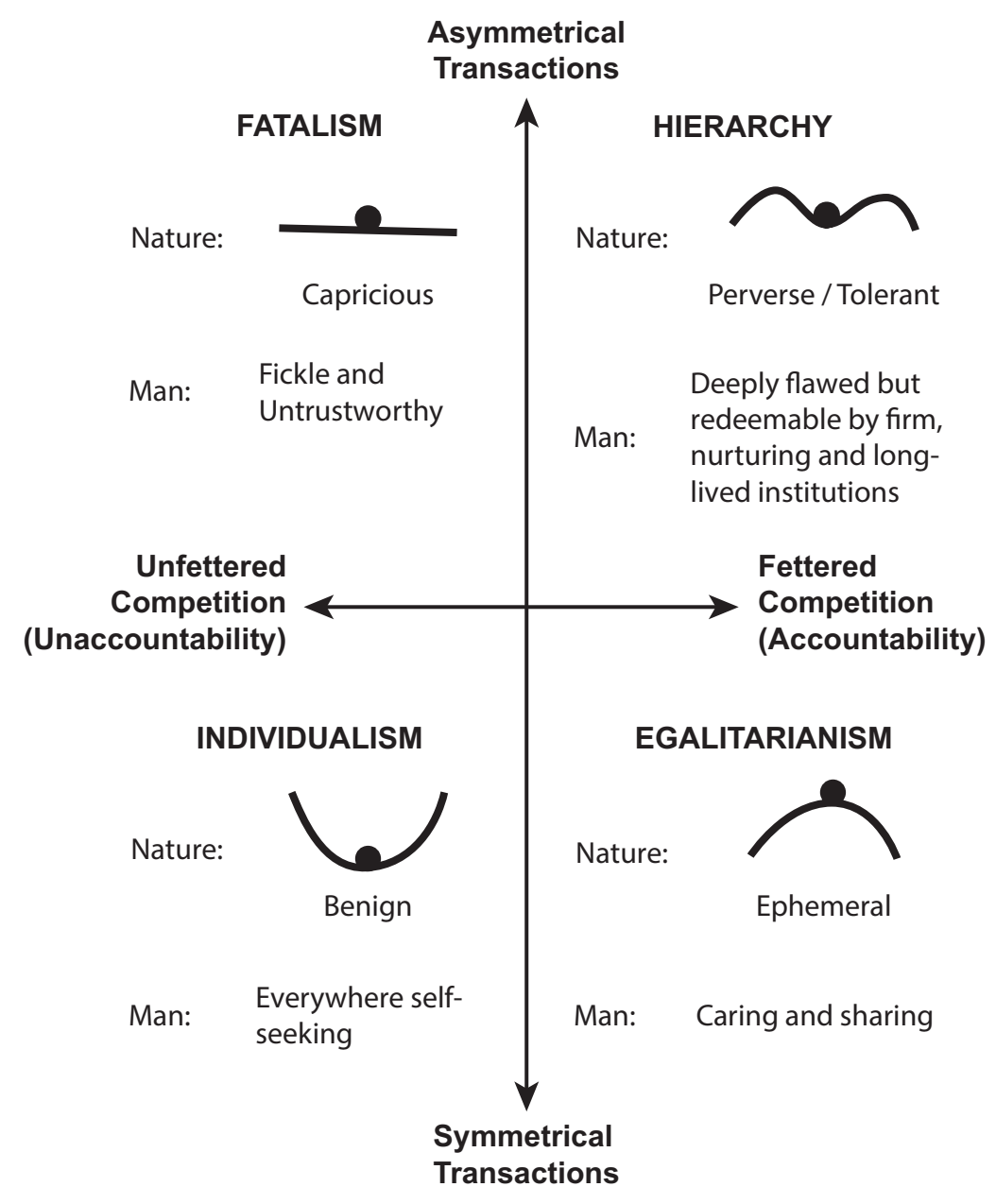

3 With just four possible destinations there are six "primary privileging": a squared-off circle (clockwise and then anti-clockwise); a figure-of-eight (again with two directions) and a figure-of-eight on its side (again with two directions). With five destinations this total increases quite dramatically, and if we allow "hybrid cycles" (with various "doublings-back") then possible cycles proliferate to infinity. 
It is an institutional theory ${ }^{4}$ : four ways of organising - or, following Durkheim, four forms of social solidarity - each of which is, at the same time, a way of disorganising the other three. Forms of social solidarity are defined as "the various ways in which we bind ourselves to one another and, in so doing, determine our relationship with naturet".5 In other words, our convictions as to how the world is, and people are, are supplied to us (as it were) by the ways in which we are caught up in the process of social life (figure 2).

For present purposes, what is crucial from all this is that there will always be four "voices", some of which, however, will quite likely be ignored in policy formulation and implementation (and especially if that is being guided by the two-voice orthodoxy; even more so in those situations where just one voice has become "hegemonic").

- The individualist voice is pro-market. It calls for de-regulation, for the freedom to innovate and take risks, and for the internalisation of environmental costs so as to "get the prices right". Since nature is "mean-reverting" - a ball in a basin (figure 2) - there is no chance our actions will trigger catastrophic collapse: exuberant trial-anderror, with the resulting technological solutions then being put in competition with one another, will ensure we quickly find our way along the best possible development path. Since there are both economies and diseconomies of scale out there, the most profitable option (i.e. the one with the lowest unit cost) is likely to be located somewhere between the extremes of "big is best" and "small is beautiful". Whoever comes closest to that appropriate scale will profit handsomely, and Adam Smith's "invisible hand" will then ensure that everyone else also benefits. Private goods, it goes without saying, are the kind of goods we need.

- The hierarchist voice is pro-control. It talks of "global stewardship" and is quick to point out that what is rational for the parts may be disastrous for the whole. Development is sustainable, according to this solidarity's icon (figure 2), only in the stable pocket between the two peaks (hence concepts such as "carrying capacity", "dangerous climate change", "assimilative capacity", a "safe operating space for humanity" and so on). So we need certified experts - Royal Societies, National Academies of Sciences, IPCCs and so on - to determine just where those peaks are located, together with statutory regulation to ensure that firms and individuals remain on the right side of them. There is a marked bias towards complex, carefully planned, centralized and large-scale technological solutions (with economies of scale being emphasised and diseconomies backgrounded) and away from the unruly and anarchic goings-on that are fostered by those who opt for appropriate scale (individualism) or (as we will see in a moment) for small-is-beautiful (egalitarianism). Public goods - foremost among which are regulation and security (water, food, energy, environmental, human, cyber and so on) - loom large for those who speak with this hierarchical voice.

- The egalitarian voice tends to be strident and critical. It scorns the idea of "trickle down", argues for zero growth and, with its heightened concern for equity, is convinced that the focus needs to be on "the poorest of the poor". Its icon, in which the least perturbation can provoke total collapse (figure 2), justifies the call for major shifts in our behaviour so as to bring our profligate consumption down within the limits set by Mother Nature. This is seen as perfectly feasible, human nature being essentially caring-and-sharing (until corrupted by those inequality-imposing markets and hierarchies). This is just as well, since the alternative is a world populated, as the uncompromising environmental movement Earth First! puts it, by “just cockroaches and Norway rats" (and, some might wish to add, the Rolling Stones' guitarist Keith Richards). And it is common-pool goods together with small-scale, decentralised and "empowering" technologies, that are key to the achieving of that radical change, before it is too late!

- Fatalist actors see no possibility of effecting change for the better, and tend not to have a voice. Unlike with the other three solidarities, their icon does not enable learning of any kind: push the ball this way or that on the flat surface and the feedback is everywhere the same (figure 2). With no possibility for strategising behaviour, the focus has to be on devising short-term coping

4 As is made clear in 6 and Mars (2008) the title of which is “The Institutional Dynamics of Culture: the New Durkheimians”.

5 This is the generalized version of the definition that is set out on pages 18-19 of Rayner et al., 1999. 
mechanisms. Even so, they have a vital part to play, because we need to heed their counsel (even though we may have difficulty hearing it) so as not to waste time and money over things about which we can do nothing: "crying over spilt milk", "shutting stable doors after the horses have bolted" and so on. "Give us the job and we will finish the tools" is the rather unkind verdict on their input to technology; unkind because fatalist actors are often good at improvising and at making do with very little. For all that fine talk among the other solidarities - about private, public and common-pool goods - fatalist actors know that these are really all club goods. "Those businessmen, government officials and civil society organisations", they assure one another, "have got it all sewn up and we, as always, are on the outside." ${ }^{\prime}$

Now, with cultural theory explained, I can get back to those "interesting transitions" that, I (and Harald Katzmair) have suggested, give us the innovation cycle (figure 1). This figure (figure 1 combined with figure 2, to be precise), once we have privileged some of its transitions along the lines Harald Katzmair has suggested, is identical - in terms of its dynamics, that is, not its substance - to the one that gives us Crawford ("Buzz") Holling's celebrated ecocycle (figure 3).

Fig. 3: The complex critique of the conventional assumptions about natural systems. Source: Thompson (2008), p. 100, re-drawn from Holling [1986, p. 307] so as to be homologous with figures 1 and 2.

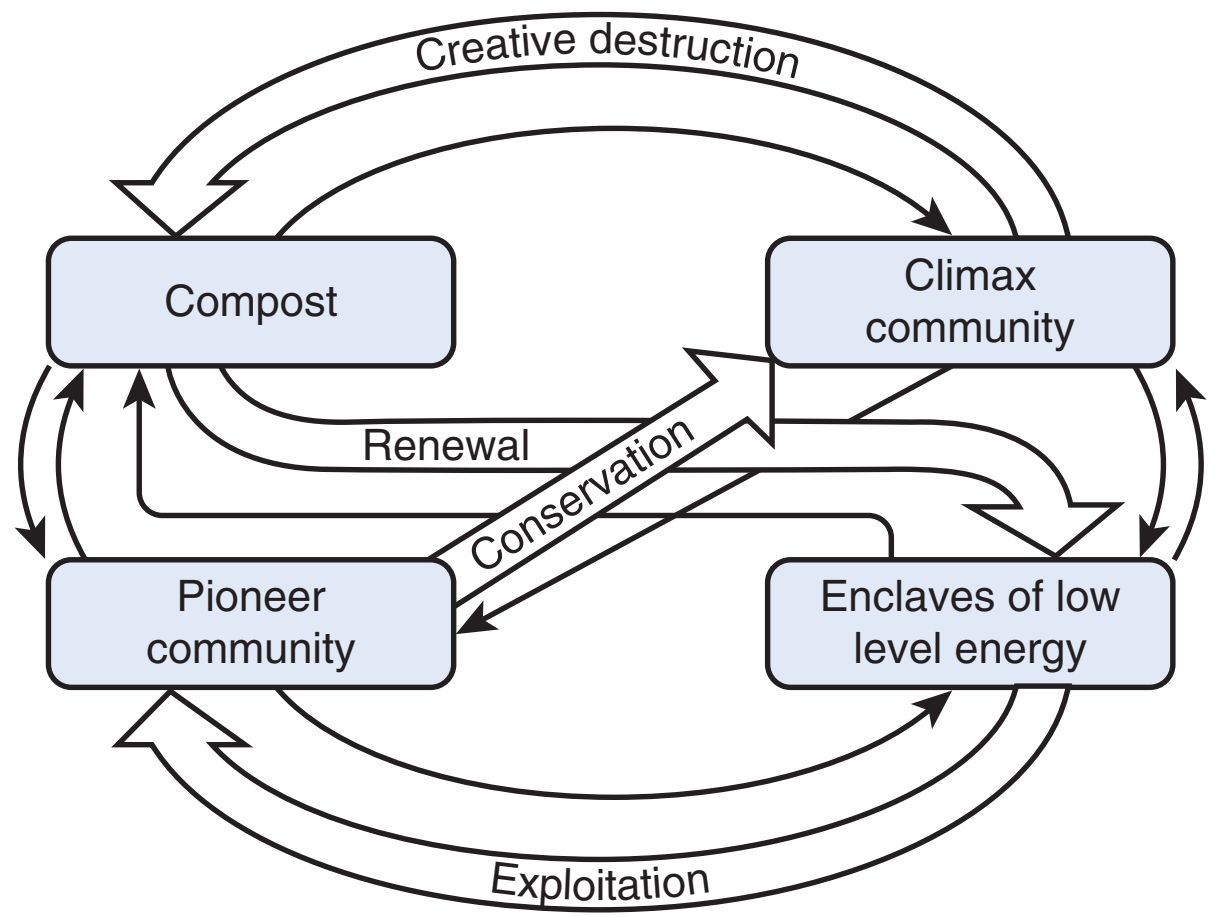

6 The fifth solidarity, Autonomy (characterised by a hermit-like social withdrawal), while it provides a useful vantage-point from which the reflexive policy analyst or engineer can obtain a helpful view of the fourfold fray, does not have much to contribute to the innovation process. When the Dalai Lama was visiting Berkeley University, back in the 1980s, concerned students were somewhat miffed by his take on climate change: "If it's solvable, no problem; if it's not solvable, no problem!" For some clarification of just where and when it is okay to leave out the autonomous solidarity, see the section headed "User-Friendly Cultural Theory" (pp. 13-15 of Thompson et al., 1999). 
In the conventional account, we have just two ecological ways of organising: the pioneer community (with its r-selected species) and then the process of "conservation" (or "succession") leading to the climax community (with its K-selected species). And that, as long as nothing wings its way in from the outside, is the end of the road. "Not so", says Holling, drawing on a famous (and still bitterly contested) paper by Robert May (May, 1972), in which he argues that the climax community (with all its niches and symbiotic relationships) will eventually complexify itself to the point where it undermines its own stability: a dramatic transition that Holling, well aware of the Schumpeterian parallel, calls "creative destruction" (figure 3). Nor is that the end of the ecological road, because, with the whole place suddenly awash with "primitive capital" - loose energy characterised by compost - the way is open for the "unspecialised and cooperative fence-builders" (micro-organisms, for the most part) to come in and fix it, before it is leached away, by gathering it into small enclave-like bundles. The scene is then set for the re-entry of the pioneer community - rodents, weeds, gannets and so on - who are adept at exploiting the energy "gradients" between these little bundles. And so it goes, round and round, and entirely endogenously (as long as the sun is shining; such living systems cannot survive without energy being pumped in from outside). However, it is actually full spiral, not full circle. In going around the cycle, all sorts of features that were not there to start with emerge, and other features that were there disappear. So it is that increment-cum- depletion, as things go round and round, that results in the evolution of the overall system. While cycles are usually seen as incompatible with evolution - the former going nowhere, the latter moving things ever onwards - the argument is that (as with the bus in this paper's title) they are essential.

These two homologous systems - one social and technological, the other natural and ecological - being complex (in the mathematical sense of that word) ${ }^{7}$, cannot be described in terms of equations. But they can be explored with the help of computer simulations. One of these - it is aimed at exploring the social and technological system but draws on the theory of surprise pioneered by Holling (see Thompson et al., 1990; Ingram et al., 2012) - is an ABM (an AgentBased Model) called the Surprise Game. It is called a game, not because you can play it (like Monopoly, say) but because you can play with it, and it consists of a world of just 30 "firms", each of which, by switching between just four strategies (each of which aligns with of our four voices), has to survive (and, if possible, prosper) in its environment, which is nothing more than the other 29 firms. The result (see figure 4 ) is undoubtedly cyclical, but it is erratically cyclical: not at all the same as the sinusoidal oscillations of an unforced pendulum (which, being simple in nature, can readily be cast in the form of an equation).

This system (as is evident in figure 4) never settles down into some dynamic equilibrium, nor do we ever see a clear "winner" emerging. It never exact-

Fig. 4: Surprise Game - firms by strategy-50 period simulation. Source: Ingram et al. (2012), p. 399.

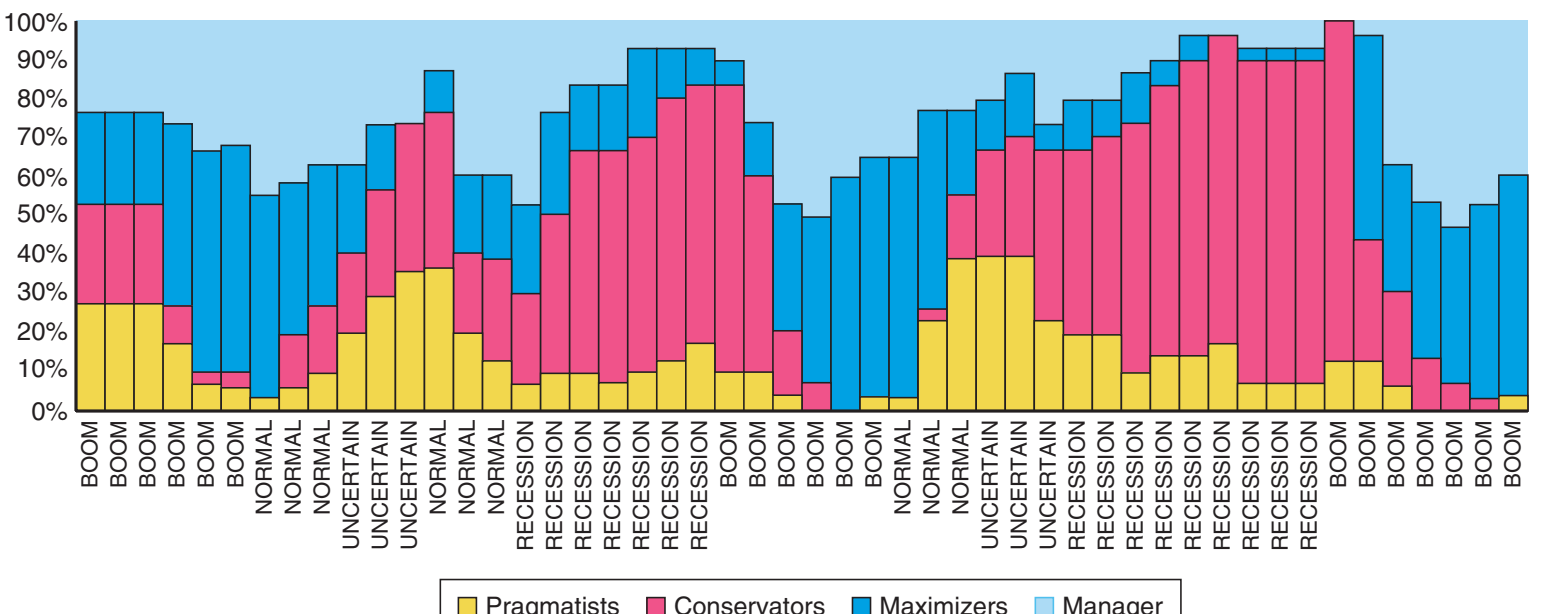

7 Indeterminate, unpredictable, sensitive to initial conditions and so on. Gleick (1987) is a good guide. 
ly repeats itself (we have run the game in its various versions, for thousands of rounds), nor do any of the ways of organising/strategies ever go into permanent extinction (though they do experience some tremendous ups-and-downs, along with some tremendous learning and unlearning of lessons by their constituent "agents"). In other words, it is a disequilibrium system: one of a family of systems, to which Holling's ecocycle also belongs, known as epigenetic landscapes.

Fig. 5: An epigenetic landscape cycling (to the surprise of the agents who have generated it) through the four myths of nature. Source: Thompson (2008, p.46).

The thicker arrows depict the transformations of the landscape that result from the ball's movement through it. The fine arrows depict the movement of the ball at the key stages of this transformational process.

The broken fine arrows indicate that the basin that marks the start of the next cycle is a different basin.

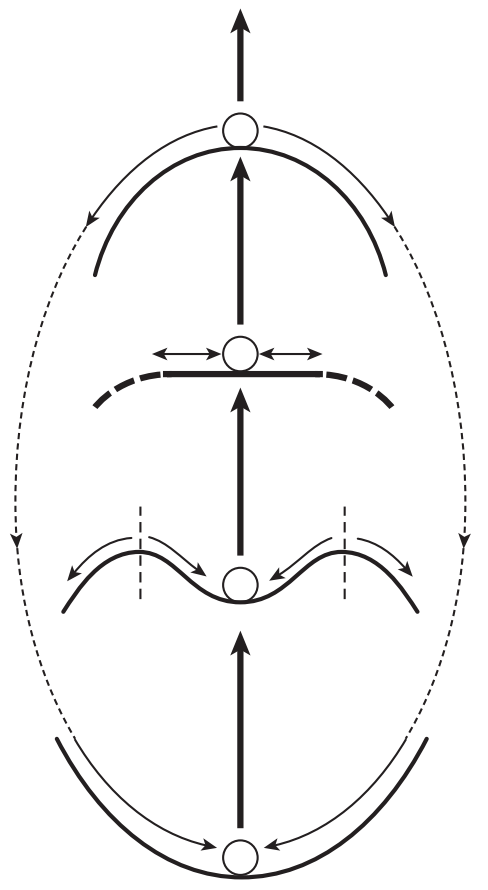

Epigenetic landscapes were first described by the biologist, Conrad Hal Waddington, back in the 1950s (Waddington, 1957). ${ }^{8}$ They are dynamical systems in which the various actors - organisms, cells, firms or whatever - in adapting to and exploiting a particular environment, eventually transform it into a different environment; a "pocket of opportunity", for instance, becoming ever shallower as more and more agents are attracted into it, eventually "imploding" and becoming a repeller, spilling its surprised occupants out across the now dramatically altered landscape; on and on (figure 5).

Or, as the evolutionary economist, Hyman Minsky (who famously predicted the 2007/8 global financial crisis but did not live to see it), has so nicely put it; "stability is destabilising". Minsky (1992) posits four "general states of economic activity" and then suggests that, in capitalist economies, there is a normal and never-ending progression through them.

- Hedge. Here, lending is primarily to businesses and individuals that clearly have the cash flows to support the repayment of both the loan principal and the interest. More financing is done via equity than through debt, with no specific assumption on future values being needed to support economic activity.

- Speculative. In this state, the cash flows of borrowers can fully support the payment of interest on debt, but not the repayment of the principal. Debts are presumed to be repaid by refinancing, with the result that debt starts to overtake equity: "high-gearing" as property developers call it. There is an assumption that the values of assets in the economy will be the same or higher.

- Ponzi. Cash flow from borrowers is not sufficient to repay either interest or principal. Debt becomes almost the sole source of financing (as with Bernie Madoff, for instance, and Ponzi himself during the Florida Land Boom that paved the way for the 1929 Wall Street Crash) and leveraged share purchases are common. The assumption is that

8 The notion of "epigenetic landscapes" is being used here in a somewhat generalized and "stretched" sense, and the mechanism Waddington describes - it has to do with the genes and cells being variously switched on and off as the cells themselves develop and diverge from one another (nerve cells and blood cells, for instance) - would be one specific manifestation. I have done this because he was the first person to open up this sort of self-transforming dynamical systems. And I can remember, back in the 1960s and 1970s, mathematicians - Réné Thom, Christopher Zeeman and Ian Stewart among them - acknowledging that as they developed notions such as "morphogenetic fields" and indeed the whole of "catastrophe theory". So I am following their lead in recognising "Wad" (as he was known) as the father of it all. The argument in favour of this "stretching" is set out in Zeeman (1977) in a paper, in the form of a dialogue between a biologist and a mathematician, that he dedicated to C.H. Waddington. 
values are going to increase to enable the paying back of interest and principal on debts.

- Collapse. Lending ceases, because lenders are uncertain about anyone's ability to pay either interest or principal. Business activity shrinks to the extent that debt was a necessity, only activity that can be financed out of current cash flows continues, and there is no certainty about the future valuations of assets. Transition back to the hedge state can be rapid or (as with the 2007/8 global financial crisis) prolonged, and the length of time spent in collapse can be heavily influenced by government intervention in the markets (as, for instance, we have recently seen with "quantitative easing").

So here we have yet another cycle based on an epigenetic landscape. And, if we add in the various major technological transformations - steam, the railways, micro-processors and so on - that seem to happen every 50 or so years, we can use it to generate those famous phenomena (phenomena that have been consistently denied by mainstream economists): Kondratieff (or long) waves (Mars and Thompson, 2013). But (and it is a big but) Minsky's cycle, though it certainly demonstrates the stability-is-destabilising principle, is essentially a credit cycle (driven, it seems, by just one character: Mr. Greedy, also known as the Rational Utility-Maximiser) and not an innovation cycle which, I have been arguing, requires that there be four characters, only one of which is Mr. Greedy (the upholder, that is, of the individualist solidarity and exemplified by those who, in the Surprise Game, follow the Maximiser strategy: figure 4).

- While the addition of these transforming (or disrupting) technologies gives us something that looks like a series of Kondratieff waves, it does not tell us anything about the innovation processes that gave us them; each, rather, is simply a deus ex machina (like the punch line in that joke about an economist marooned on a desert island: "Assume a tin-opener").

- In Minsky's third state of economic activity, everyone is a Ponzi - a peddler of pyramid schemes - which, unfortunately, does not comport with the real world. Yes, as things move towards collapse, we find Ponzis thicker on the ground than during the other states, but there are many who elect not to join them: those characters like Keynes, for instance, who follow a "contrarian" investment strategy (essentially, doing the exact opposite of what all the lemmings are doing). And, of course, there are also those who stick with their Manager (hierarchist), Conservator (egalitarian) or Pragmatist (fatalist) strategies through thick and thin (as is evident in our Surprise Game simulation: figure 4).

- Moreover, it is difficult to see how, after collapse, our Mr. Greedy can achieve the transition back to hedge without first morphing into Mr. Careful (i.e. egalitarian). On top of that, this transition back to hedge, for better or for worse, involves government intervention, and that means that Mr. Moderation (hierarchy) is also there in the strategic mix. In other words, and this is where we need to put the institutional into evolutionary economics, if Mr. Greedy is there then all the others will be there too. This, a little more formally stated, is cultural theory's requisite variety condition (Thompson et al., 1990, p. 4).

- Some confirmation of this requisite variety condition comes from the credit cycles that have long been familiar to anthropologists: most notably the spectacular ups-and-downs that accompany the ceremonial (and competitive) exchange of pigs in the highlands of New Guinea. The key extenders of credit here are the "Big Men" (as these individualistic characters are called in pidgin) who, while taking care to avoid the "Rubbish Men" (fatalism), induce ever higher levels of credit among their followers, along with a massive increase in the overall pig population. Eventually, as the number of pigs promised diverges ever further from the number that can actually be delivered, the entire piggy pyramid collapses. Most of the Big Men go bust, with their disappointed followers having no option but to resort to the sparse comfort of their relatives within the traditional lineage structure that, during the upturn, had been so overshadowed by all the network-building frenzy whipped up by the Big Men. In other words, things shift, markedly and rapidly towards the predominantly hierarchical state of affairs that had existed before the start of the upturn. The literature on these credit cycles can therefore be read as an early essay in institutional evolutionary economics (Thompson, 1980; Thompson, 1979/2017). 
Now, having pinned down just what sort of system we are dealing with, having clarified the similarities and differences between innovation cycles and credit cycles, and having built a "bottom-up" and rather stylized agent-based model of it, let me turn to the policy implications of it all. These are set out, at considerable length, in the book Aid, Technology and Development: The Lessons from Nepal (Gyawali et al., 2017) and at the heart of that book are seven technology case studies - goods-only ropeways, electric vehicles, micro and small hydropower, biogas, large hydropower, water supply and sanitation, and community forestry - each of which, of course, is caught up in the four contending ways of organising, knowing and justifying.

The overarching lesson is that clumsiness - each of the four voices heard and responded to by the others, as happened (sequentially: one voice after another, as in our innovation cycle) with the bicycle, for instance (Bijker, 1995), the internet (Tranvik and Thompson, 2011) and Unilever's "Frish" lavatory rim-block (Thompson, 1989) - is far superior to elegance: just one (or a combination of two) voices drowning out the others, as has happened with nuclear power, for instance (Thompson, 1995), irrigation in Iran (Yazdanpanah et al., 2013) and with so many aid-funded interventions in the developing world (most notably large hydropower projects, wastewater treatment facilities and so on: see chapter 1 of Gyawali et al., 2017). A further lesson is that there is much to be gained by "speeding-up" this sort of sequential clumsiness: tightening the fourfold innovation cycle until it comes close to being just a point. And this, as we will see in this concluding section, is pretty much what has been achieved with one of these Nepal case studies: goods-only ropeways.

\section{Some policy lessons from Nepal}

Development (throughout the 60-odd years that constitute the Age of Aid) has always been over-elegant: some combination of just individualism and hierarchy. But 15 or so years ago, a Nepali activist group - the egalitarian voice - managed to get through to Chris Patten who, being at that time a European
Commissioner, was able to persuade the European Union to devote $€ 75,000$ to a goods-only ropeway, rather than to the road-building programme that, thanks to its hierarchical bias, it normally spends our money on. This egalitarian voice is clearly evident in the project being labelled a "conservation ropeway", its primary stated aim being to reduce the pressure on the forest.

But, of course, the project still had to find its way through all the hierarchical procedures - "baseline studies", "screening tools" and so on - by which development aid is habitually delivered. It also had to mesh with the individualistic (i.e. market-focused) aspirations of the very poor villagers it was designed to help (the forest being a crucial component of their farming system). In other words, it would have to be clumsy: enabling maximum scores on the axes of both accessibility and responsiveness: a definition that, expressed in this way, ties cultural theory in with (indeed re-furbishes) the classic theory of pluralist democracy (Dahl, 1989; Ney, 2009). Being cast in terms of institutional variety (i.e. cultural theory) and deliberative quality (i.e. pluralist democracy), this is a definition that is seriously at odds with the sort of logical calculus that underlies the longestablished precepts of policy analysis (figure 6). ${ }^{9}$

Just south of Nepal's capital city, Kathmandu, a small and unsurfaced road climbs to the rim of the Kathmandu Valley and then goes off down the valley on the other side. If you stand on the col and look across half-left you will see, just a couple of kilometres away, an extensive danda - a high, rounded ridge - and this one, Bhattedanda, has several villages on it and rather a lot of cows and water buffaloes which, between them, produce a fair amount of milk. The trouble is that, between the col and the danda, there is a 1,000 metre chasm. In consequence, by the time the farmers have carried their milk down and then up, and got it onto the milk-lorry to Kathmandu, it is sour. So they have had no option but to boil it down into a condensed form, khuwa, consuming vast amounts of fuelwood in the process. On top of that, khuwa fetches a much lower price in the city than fresh milk.

9 Re-writing the precepts of policy analysis (as is explained in the final chapters of Verweij and Thompson, 2011) is the daunting challenge that was first raised by Aaron Wildavsky who, having founded the world's first graduate school of Public Policy (at UC Berkeley), was well-qualified to venture onto such high-risk terrain. Since then, the re-writing has preceded apace (e.g. Ney, 2009; Verweij, 2011; Scolobig et al., 2015; Thompson and Beck, 2014 and, of course, Gyawali et al., 2017). 
Fig. 6: Re-writing the precepts of policy analysis. The "curvy surface" diagram is from Thompson (2008), p. 15.

\section{LOGICAL CALCULUS}

1. Ensure a single and agreed definition of the problem.

2. Celarly distinguish facts from values.

3. Set up a single metric (dollars, lives saved, etc.) so as to evaluate and compare options.

4. Optimize around the best option.

The second-hand Austrian ropeway, in spanning this chasm, gets the milk to the lorry in just 20 minutes, and then all the way to Kathmandu while it is still fresh. The villagers get a better price for their milk, they are relieved of the twin drudgeries of boiling it down into khuwa and carrying it all the way down and then up to the road, and the pressure on the forest is massively reduced. Nor is that anything like the end of it. The ropeway, initially, was powered by a diesel engine but the villagers, once the project had been handed over to them, got onto the internet and worked out how to convert it to electricity. Since the electricity is from medium-scale hydropower, they have effected the transition from fossil fuel to renewable energy and reduced the ropeway's running costs to a quarter of what they were paying for the diesel (which had to be imported from India). The only fossil fuel now is the milk-lorry, and even here there has been a saving because, where in the past it came up empty, it now carries goods destined for the danda: sacks of rice-chaff, for instance, as a supplementary feed to increase the fat content (and the market price) of the milk; sheets of corrugated iron to replace the thatched roofs, and bags of white cement for the frescos in the new gompa (Tibetan Buddhist temple).
In a somewhat informal survey - the Maoist insurgency being at its murderous height at that time and in that area - we asked a number of the villagers how they would rate the quality of their life now, if they took 100 as the score for how it was before the advent of the ropeway. "One hundred and forty" was the average, and that from farmers who, as we all know, are famously pessimistic.

So here is a fine example of a clumsy solution: a solution in which those who speak with the different voices all get more of what they want (and less of what they don't want) than they would have got if they had somehow managed to silence the other voices and impose their elegant solutions.

- However you choose to measure it, this is economic growth - development as defined in the conventional "aid paradigm" - achieved, moreover, by means of a carefully planned intervention that would never have happened "autonomously". So those who speak with the hierarchical voice have certainly got a lot of what they want.

- Individualistic actors also come out well: incomes increased substantially, along with a host of innovations that have shifted them away from a precarious and drudgery-intensive subsistence 
agriculture and onto what is, increasingly, a lucrative form of market-gardening. Like all South Asian cities, Kathmandu is growing fast - from 300 thousand to 3 million in just the ten years of the "People's War" - and ropeways, such as the one to Bhattendanda, can massively expand accessible food production, even with just the existing road system.

- And those who speak with the egalitarian voice, though they may not have got zero-growth, have secured the conservation of the forest, along with a convincing demonstration of how to achieve the "leap-frog" transition from fossil fuels to renewables.

- Moreover, and this is where we come to the fatalized margins, it is the "poorest of the poor" who have benefitted the most. Even more so, now that the ropeway has been extended to the next dan$d a$ : a danda so impoverished that hitherto could not even get its khuwa to market. Indeed, it used to be said of it that all it was good for was producing Maoist insurgents.

As a postscript, I should mention that many of those who, 15 or so years ago, were intent on shooting us are now vocal and active participants in Nepal's democratic system. And one among us former targets - Dipak Gyawali - is now "official advisor on energy and water policy" to the Dash Maoists who, having split off from the original Maoists, are now Nepal's (and possibly the world's) furthest-to-the-left political party. For good measure, he also performs the same role for the Monarchists: the furthest-to-theright party.

\section{References}

Bijker, W.E. "Of Bicycles, Bakelites and Bulbs: Towards a Theory of Sociotechnical Change". Cambridge, MA: the MIT Press, 1995.

Dahl, R.A. "Democracy and its Critics". New Haven, CT: Yale University Press, 1989.

Douglas, M. “Cultural Bias”. London: Royal Anthropological Institute (Occasional Paper No. 35), 1978.

Gleick, J. “Chaos: Making a New Science”. New York: Viking Penguin, 1987.
Grauer, M., Thompson, M. and Wierzbicki, A. (eds) "Plural Rationality and Interactive Decision Processes”. Berlin: Springer Verlag, 1985.

Gyawali, D., Thompson, M. and Verweij, M. (eds) "Aid, Technology and Development: The Lessons From Nepal”. London: Earthscan Routledge, 2017.

Holling, C.S. "The resilience of terrestrial ecosystems: local surprise and global change", In W.C. Clark and R.E. Munn (eds) Sustainable Development of the Biosphere. Cambridge: Cambridge University Press, 292-316, 1986.

Ingram, D., Tayler, P. and Thompson, M. "Surprise, surprise: from neoclassical economics to e-life", ASTIN Bulletin (Journal of the International Actuarial Association), 42(2), 389-412, 2012.

Mars, G. and Thompson, M. "Individualism versus hierarchy: Kondratieff and his crime waves: The behavioural underpinnings of booms and slumps", In G. Mars, Locating Deviance: Crime, Change and Organisations. Farnham: Ashgate, 149-176, 2012.

May, R. "Will a large complex system be stable?", $\mathrm{Na}$ ture 238, 413-414, 1972.

Minsky, H. "The financial instability hypothesis", The Jerome Levy Economics Institute Working Paper Series, 1992, Reprinted in G. Argyrons and F. Stilwell (eds) "Economics as a Social Science: Readings in Political Economy”. North Melbourne: Pluto Press, 201-203, 2003.

Ney, S. "Resolving Messy Policy Problems". London: Earthscan, 2009.

Rayner, S., Malone, E.L. and Thompson, M. "Equity issues and integrated assessment", In F.L. Toth (ed) Fair Weather? Equity Concerns in Climate Change". London: Earthscan, 1999.

Scolobig, A., Thompson, M. and Linnerooth-Bayer, J. "Compromise not consensus: designing a participatory process for landslide risk mitigation", Natural Hazards 81 (Supplement 1), 69-88, 2016.

Thompson, M. "Rubbish Theory". Oxford: Oxford University Press. New edition, with new foreword (by J. Reno), new introduction and major new af- 
terword (co-authored with M.B.Beck). London: Pluto Press, 1979/2017.

Thompson, M. “The geometry of confidence: an analysis of the Enga te and Hagen moka, a complex system of ceremonial pig giving in the New Guinea highlands", In J.C. Mitchell (ed) Numerical Techniques in Social Anthropology. Philadelphia: Institute for the Study of Human Issues, 235-272, 1980.

Thompson, M. "Surprises from systems, natural and cultural", Speculations in Science and Technology, 12(4), 299-306, 1989.

Thompson, M., Ellis, R.E. and Wildavsky, A. "Cultural Theory”. Boulder CO: West View, 1990.

Thompson, M. “Technology as a social and cultural process”, In J. Monk and M.E.A. Schmutzer (eds) Views on Technology and Culture. Milton Keynes/ Vienna: Faculty of Technology, Open University/ Technical University of Vienna, 95-110, 1995.

Thompson, M. Grendstad, G. and Selle, P. (eds) “Cultural Theory as Political Science”. London: Routledge, 1999.

Thompson, M. "Organising and Disorganising”. Axminster: Triarchy Press, 2008.

Thompson, M. and Beck, M.B. "Coping with Change: Urban Resilience, Sustainability, Adaptability and Path Dependence" [Online], UK Government Office for Science Foresight Future of Cities Project, www.gov.uk/government/publications/future-ofcities-coping-with-change, 2014 (Accessed September 3, 2017).

Tranvik, T. and Thompson, M. "Inclusive by design: the curious case of the internet", In M. Verweij and M. Thompson (eds) Clumsy Solutions for a Complex World. Basingstoke: Palgrave Macmillan (revised paperback edition), 204-225, 2011.

Verweij, M. "Clumsy Solutions for a Wicked World". Basingstoke: Palgrave Macmillan, 2011.

Waddington, C.H. “The Strategy of the Genes”. London: Allen and Unwin, 1957.

Yazdanpanah, M., Thompson, M., Hayati, D. and Zamani, G.H. "A new enemy at the gate: tackling Iran's water super-crisis by way of a transition from government to governance", Progress in Development Studies, 13(3), 177-194, 2013.

Zeeman, E.C. "A dialogue between a biologist and a mathematician", Catastrophe Theory: Selected Papers 1972-1977: 267-286. Reading: Massachusetts: Addison-Wesley Publishing Company (Advanced Book Program), 1977.

6, P. and Mars, G. "Introduction", In P. 6 and G. Mars (eds) The Institutional Dynamics of Culture (2 vols.). Farnham: Ashgate, 2008. 
Commission for Interdisciplinary Ecological Studies (KIOES)

KIOES Opinions 6 (2017): 20-26.

doi: 10.1553/KIOESOP_006

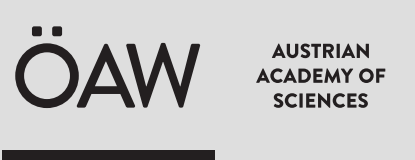

\section{Co-creative Innovation for Sustainability: Creating Robustness in a Rapidly Changing World Through Inter- and Transdisciplinary Research}

VEREna Winiwarter, Gertrud Haidvogl and Stefano Brumat

Fig. 1: Opening of the regulated Danube in Vienna in 1875 (Source: Wikimedia Commons).

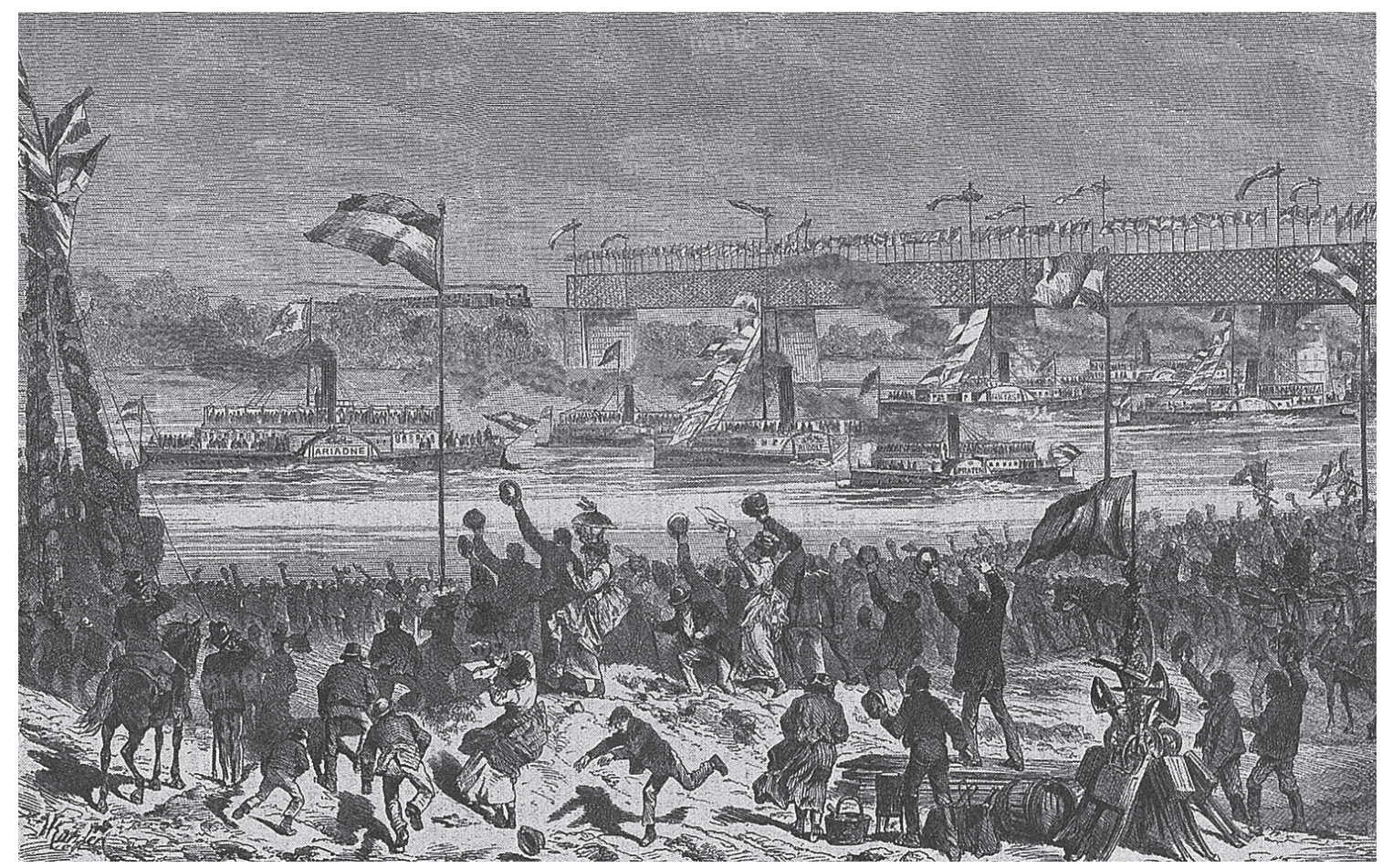

\section{Introduction}

Vienna is an exceptional river city because it is situated at the upper section of the Danube. Upper river sections are characterized by steep slopes, swift currents and high sediment dynamics, creating a dangerous neighbourhood for humans and their infrastructure. Between 1715 and 1783 alone, newspapers in the United Kingdom reported 14 times on Viennese bridges over the Danube damaged by ice floes and the ensuing floods, the situation obviously being bad enough to be newsworthy (Winiwarter in Costlow et al., 2017).

Not least because of hopes of diminishing flood risk, the Great Danube Regulation depicted in figure 1 was a reason to celebrate for the Viennese gathered at the banks. They were looking at a man-made river bed, an engineering marvel of international recognition that had been years in the making. Already seven 
years earlier, “The Mechanic's Magazine” had reported on the plans: "The Emperor of Austria has adopted a plan for improving the course of the Danube, to be put at once into execution. This project has been under the consideration of a committee for the last five years, and when finished will prove of the highest importance, not only in preventing future inundations of various Austrian districts, and with which the city of Vienna was annually threatened, but also in giving a strong impetus to the shipping trade of the Danube. The cost of carrying out the work is estimated at 24 millions of florins." (The Mechanic's Magazine, London, 25. Sept. 1868, p. 256).

Avid readers of the popular Magazine, then in its $45^{\text {th }}$ year of publication, would have noticed that this was the second report on the Danube in the same issue. The other report came from the mouth of the river: "OWING to the labours of the European Commission at Sulina, which has used every exertion to deepen the channel of the Danube there, and lessen the difficulties of entering the roadstead, accidents have diminished in a considerable proportion. From 1855 to 1860 , before the execution of the works, the number of shipwrecks occurring there was 0.39 percent, of the vessels leaving. From 1861 to 1866 the proportion was only 0.09 . In addition, for a great length of time, there has been no loss of life." (The Mechanic's Magazine, London, 25. Sept. 1868, p. 255)

What do $19^{\text {th }}$-century engineering marvels have to do with $21^{\text {st }}$ century concerns about co-creative innovation for sustainability? If one considers sustainability as a triangulation of ecological, social and economic concerns, the economic interest in riverborne trade was definitely important, but so was human welfare, or social concern. By engineering interventions, humans would be protected from floods or death by shipwreck. This ethical concern about the centrality of long-term human well-being is at the heart of intergenerational justice, or sustainability by another word. The stunning cost of 24 million florins for the Vienna regulation makes clear that the works were necessarily a public investment, beyond the possible means of private entrepreneurs. We might well qualify these two interventions as innovations for sustainability, even if we might judge their ecological effects differently today.

But what about the co-creative part of innovation? While less apparent, both cases are good examples of co-creation. In both cases, committees or commissi- ons are mentioned. The Danube Regulation Commission was founded in January, 1867 and tasked with preparation and execution of the regulation works. The Austrian State (then the Habsburg Monarchy), the Province of Lower Austria and the City of Vienna were equally represented in the commission, which mirrored the division of cost. Bonds were issued to finance the undertaking. The social prerequisites of this technological masterpiece are numerous: The institutions of state, province, and city government and that of a joint commission, a financial market open to bonds, and financial institutions capable of issuing them, all were necessary before the first spade could be sunk into the alluvial soil. Means to negotiate and secure public interest in the regulation are also to be mentioned: Media to inform people, and, of course, governance institutions such as city councils or parliaments for decision-making.

Bonds rest on the belief of stability of the financial system and so we might allow for the necessity of a constitutional state granting security for investments as a prerequisite.

In the Sulina case, a "European Commission" - referring to the European Commission of the Danube, an international legal entity founded in 1856 - is mentioned, allowing us to think of the added complexity of international co-operation on an international waterway (Cp. Ardeleanu, 2014 for an account of the socio-political complexity of the Sulina question). The decision to create such an international waterway is a result of international negotiations having taken place. Such are only possible if a common language and a common legal framework exist. The Sulina Canal and the works at Vienna are built on technology. Engineers are needed to carry out such complex work, build the necessary machinery to enable it, so a high level of technical education needs to be counted among the prerequisites. One might even count a degree of literacy and numeracy, acquired in primary schools, upon which engineering schools can build, among the preconditions. The committees are social innovations, providing negotiation space for the balancing of different interests even on an international scale as was deemed favourable after the Crimean War in 1856.

One quickly finds oneself enmeshed in a network of prerequisites reaching from education over governance to the material necessities of engineering and the existence of financial and legal institutions. The 
lauded innovations are, as we can surmise, sociotechnical. As new types of interventions into nature, they are based on new actors such as the commissions founded for this purpose. Nature also plays an important role, the threatening floods and the dangerous navigation providing reason and necessity for social and technical innovation.

The set-up of new administrative bodies such as the two commissions is the norm, not an exception. Whenever a new road of dealing with natural dynamics is to be taken, new institutions are set up. This has to some extent already happened as societies started to engage into activities for sustainable development. Cases in point are intergovernmental, transdisciplinary entities such as IPCC, IPBES or, to stay within the Danube River Basin, the ICPDR, the International Commission for the Protection of the Danube River, a body tasked with developing basinwide management principles, organizing surveys and publishing reports on the state of the environment in the basin and to interact with various governments and stakeholders to protect it. ICPDR, like IPCC, was founded as a social innovation when it was deemed necessary to deal in a new way with socio-natural dynamics.

Dealing with socio-natural dynamics (including the side-effects of interventions and the legacies of previous interventions) so that human survival under acceptable conditions is possible over the long term is the main challenge for sustainable development, and hence for the innovation needed to foster such a development. Researchers in the sustainability sciences either advocate institutional reform for the transformation to a sustainable society or argue for entirely new institutions, as new challenges arise, in particular as they diagnose ossification and obsolescence of older institutions facing new challenges.

In stark contrast to the research agenda that one would expect to be derived from such a diagnosis, the humanities and social sciences have been on the periphery of eco-innovation. This paper makes a case for including them, in fact, mainstreaming them for the benefit of eco-innovation.

\section{Humanities and social sciences are neces- sary for sustainable development ${ }^{1}$}

Sustainable development needs an innovation-oriented society based on a knowledge-intensive economy. The role of the humanities and social sciences for such a society has been acknowledged worldwide. An Australian report on the issue states this particularly clearly: "These disciplines [humanities and social sciences] provide the organisational, management, legal, accounting and marketing knowledge bases that are critical to successful innovation. They are the source of many of our insights into the human condition broadly, and to our understanding and managing the consequences of moving to a knowledgebased economy." (AAH, 2003)

Since 2012, as a service for and together with universities from several countries, we have developed a networking program for the sustainable development of the Danube River Basin², a flagship network of the "Danube Strategy" (EUSDR) called Danube:Future. Co-creative processes are central to the success of the network. One such initiative is the founding of international, interdisciplinary training schools for $\mathrm{PhD}$ and young Post-Doc researchers from the Danube countries. Four schools have so far taken place and more are planned. Another co-creative process was the development of a research-community-based White Paper on the research needs for a sustainable development of the Danube River Basin. Some of the insights presented in the White Paper are central to the argument of this paper:

The Basin is a vast, multilingual and multi-ethnic space divided into many nations but sharing a common natural heritage. Its inhabitants are, for better or worse, connected by the Danube and its many tributaries. One person's effluent is another one's drinking or irrigation water; watersheds connect large areas laterally and longitudinally above- and below ground. They are therefore real laboratories for experimenting with the collaborative effort necessary for sustainable development of society. During our various networking activities, we identified three areas in which Humanities and Social Sciences contribute in

1 This part of the argument has first been presented in 2015 at a Panel Discussion on the Käte Hamburger Kollegs of the German Ministry for Science in Berlin (June $\left.9^{\text {th }}, 2015\right)$.

2 http://www.danubefuture.eu 
particular to facilitate sustainable design and development of societies.

The first area is Cultural Heritage. The Humanities and Social Sciences are urgently needed to foster sustainable development in the war-torn Danube Basin with its high potential for conflict due to the contested legacy of nationalism, genocide and wilful destruction of the cultural heritage to destroy identity. The Council of Europe, in a 2011 resolution, called for exploring cultural heritage for its potential to foster peace after or even instead of conflict (Council of Europe, 2011). The council argues that heritage provides a channel for knowledge and the mutual recognition of diversity and can thus stimulate dialogue between people and communities (Council of Europe, 2011, p. 5). Another organization, UNESCO's, work is based on the understanding that the preservation of cultural heritage has effects on development, social cohesion and peace and hence, needs to be integrated into national and local policies. UNESCO's website emphasizes the same point: "UNESCO will continue to monitor [...] highlighting the role that can be played by culture in situations of conflict or post-conflict as a 'vehicle' for reconciliation through cultural heritage". ${ }^{3}$

But immaterial ("traditions") and material cultural heritage should not be seen naively as a cure for conflict, but rather as multi-faceted and ambiguous. This is actually a good thing, as it allows for communication about it between different groups. To quote John Daniel Giblin on the issue: "[...] post-conflict healing from psychological and cultural perspectives should not be assessed based on simplistic linear and universal values. Instead, it is better understood as an intensified, but ambiguous, form of renewal based on the use of emotive symbols, as part of a larger anthropological undertaking of continuous individual or cultural (re)production" (Giblin, 2014, p. 514) . $^{4}$

The second issue is the necessity of a long-term, back-casting interdisciplinary approach to the environmental issues that lie at the core of sustainable development. The interaction between humans and dynamic, complex, moving ecosystems that are dependent on climate, morphology, soils, plants animals and micro-organisms, which have often been changed by human interventions, forming hybrid socio-natural sites, needs a long-term perspective on BOTH nature AND society. Interactions are non-linear, with time lags, threshold effects and feedbacks. Environmental issues tend to be wicked problems sensu Rittel and Webber (1973), problems that defy a simple approach. The environmental humanities are called to contribute to their resolution in co-operation with the paleo-sciences (Winiwarter, 2013; Winiwarter 2014).

The third area is participatory planning. Social Sciences and the emerging Environmental Humanities are needed for participatory planning (Vervloet et al., 2005 , p. 156f), which involves different actors such as government and non-governmental agencies, inhabitants and enterprises in a process of transdisciplinary negotiation. Experts need to be prepared to find locally fitting and accepted compromises rather than coming with a one-size-fits-all approach. When participatory planning is involved in the creation or recreation of cultural heritage, developing heritage can trigger processes of empowerment and is therefore a field of experimental democracy, which in itself is a prerequisite for sustainability. Vervloet and colleagues also point out that radical imagined futures can open a space for negotiation about more mundane and practical solutions by widening the vision of the people involved. So, in short, participatory planning can be a laboratory for negotiation and help develop democracy at the same time as promoting a sense of belonging and identity.

All three issues need internationalized approaches towards culture. International co-operation ensures that multiple perspectives are brought into the discussion on sustainable development. Not only does this make interdisciplinary co-operation easier, the richness of different scholarly traditions with their different methods and areas of expertise can thus be of service to society. Culture is central to the endeavour: In the words of John Dewey, a civilization's culture is the "shared house of meaning" - it is what allows human beings a sense of living in a world organized by meanings and values, a world that makes sense and provides fulfilling goals for action.

Cultures are ways of inhabiting and adjusting to the world and the conditions of life. Ultimately, to use the insights of John Dewey, democracy cannot merely

3 http://www.unesco.org/new/en/culture/themes/dialogue/intercultural-dialogue/

4 This argument is made more fully in the proceedings of the DIANet school 2015. See http://www.danubefuture.eu 
"tolerate" diversity; it alone of all forms of civilization requires diversity. Diversity rests on the ability of actors and organisations to encounter difference meaningfully. We must be able to employ a complex understanding of the world and its traditions to contextualize the diversity we encounter (Alexander, 1995). Turning the argument upside down shows that it is true in both directions: Democracy needs sustainable development. In an ecologically degraded world, long-term economic development is impossible and social inequality and hence, unrest, are likely to increase. Without a firm basis in constitutional states, without free media to enable informed participation, actors will not be held accountable for violations of sustainable principles. It is therefore no surprise that the German WBGU, in its 2011 flagship report, has called for a more active role of the state on the one hand, and for stronger involvement by civil society on the other hand (WBGU 2011).

Democracy and with it, sustainable development are predicated on the perpetual possibility of communication. Fields of knowledge such as the media and communication sciences, legal studies, area studies, the study of religion and that of conflict, and cultural studies in general, but even more basic, the languages and their literatures, but also music and the arts in general provide us with the communicative abilities in the "shared house of meaning", in which we can develop sustainably. Innovation cultures need to be embedded into the realm of such a shared understanding of sustainability.

Internationally operating, inter- and transdisciplinary nodes, offering spaces for co-creation and concentrating expertise in several of the fields that are central to sustainable development, are desperately needed. As pointed out in the introduction, the WBGU, like the IPCC, IPBES, but also networks such as ICLEI or even Danube:Future are by themselves new types of organisations that can be understood as such nodes. Involvement of the humanities in many such nodes remains marginal, as has been shown for IPCC (Holm and Winiwarter, 2017).

\section{Ecologies of innovation in the Danube river basin and beyond}

Apart from involving the humanities and social sciences in the pursuit for a participatory plan- ning-based development of cultural heritage across borders with a long-term perspective in mind, the concept of innovation as such needs to be framed adequately for the task, as this has policy implications. "Characterizing S[ystems of] I[nnovation] as evolutionary systems [...] has implications for policy-making, in both firms and governments. For the first, government policy to support innovative activities must find a balance between the individual and the collective. In general terms, policy-making for innovation should not be seen as a matter of picking an individual winner, although strong innovators are important. Policy is instead a question of supporting interactions in a system, especially those that help identify existing, and create new, technical and economic opportunities. This implies that certain types of interactions, or certain types of technologies and sectors, should be supported rather than others when the first offers greater innovation opportunities. Due to the importance of past and existing competences and experiences for development of the new, however, the feasibility of alternative directions has to be evaluated" (McKelvey, 1997, p. 220).

Supported by such policies, sustainable innovation can account for socio-ecological inheritance, longterm and side-effects and be directed at developing tools for precautionary action. Such innovations might actually benefit from the diversity across the many nations, languages and histories in the basin, because there might be an edge-effect for innovation systems like being reported for ecosystems, with the highest biodiversity occurring across borders between ecosystems (e.g. a lake shore, a forest clearing or margin). But integration, despite being lauded theoretically, often remains wishful thinking.

According to leading interdisciplinarity theorist Katri Huutoniemi, the integration of knowledge across academic disciplines and the accountability of science to society are (the) two major science policy issues. She views interdisciplinarity as a mode of epistemic accountability across disciplinary boundaries, which promises to make academia more than the sum of its disciplinary parts. Interdisciplinarity is not simply a category of research, but involves a social epistemic mechanism of coordination, control, and compromise between disciplinary regimes of knowledge.

Due to being situated on the borders between disciplines, interdisciplinary research operates in an accountability environment that is contingent on more 
than one discipline: it is obliged to actively search for an audience, consider what is worth investigating, and struggle with norms of good conduct. This is also why interdisciplinarity appears resistant to definition and evaluation: it keeps challenging the prevailing epistemological structures (Huutoniemi, 2016). Transdisciplinary research, or better, the many forms of co-creation of the robust knowledge needed for times of high risk and unpredictability are even more of a challenge to the existing systems. Super-wicked problems such as climate change can be tackled only in a culture fostering sustainable innovation.

Sustainable Innovation needs to be based on multiple criteria for decision-making and a culture of precaution coupled with awareness of long-term effects challenges institutions. It will set a process of change in institutions in motion, even if they do not actively engage in it.

The hypotheses we offer in conclusion address different aspects of transdisciplinary co-creation. Rather than just involving new roles (the scientist, the entrepreneur, the bureaucrat, the community organizer, the facilitator etc.) sustainable innovation is based on changes of these roles. We already know the sciententrepreneur (think of Craig Venter or Elon Musk as a role model), but how about the "facilitatist", the "community entrepreneur" and others?

All involved organizations (the university, the research center, the start-up, the science ministry, the community), are non-trivial systems that are deeply challenged by these changes and prone to react by an internal split between changers and preservers. Sustainable innovation happens outside the comfort zones of organizations and their members and hence, needs special zones of fostering (including incentives and high-risk funding). The needed innovations are based on inter- and transdisciplinary knowledge. They are not merely technological, but are at core social challenges or at least involve such challenges. To boost their performance, sustainable innovation systems need a multi-criteria-based, forward-looking, formative culture of evaluation rather than indicator-based ex-post assessments (Krainer and Winiwarter, 2016). Sustainable innovation as a multiple niche strategy has to account for socio-ecological inheritance, long-term and side-effects and develop tools for precautionary action. Therefore, sustainable innovation means to re-think "innovation". This involves changing its scoping procedure, its incentive structures and its toolboxes. New tools are needed to adopt a precautionary attitude to become innovative within planetary boundaries. Changing science governance to embrace sustainable innovation is not just about new ways of funding, it is about implementing, perhaps even mainstreaming, transdisciplinarity in the entire governance chain, from designing new educational offers, to publication outlets, performance measures of individuals and institutions to multi-criteria-based funding schemes and real incentives for implementation. In this process, the role of scholars themselves will change, and they might find themselves ill equipped for the new tasks.

When, 100 years from now, the new ecologies of innovation for sustainable development of the early $21^{\text {st }}$ century will be investigated, the analysis might well show that the education system itself was profoundly affected, with new programmes appearing, with new, transdisciplinary curricula fit for the emerging job markets. Researchers might also find that new types of organizations (such as the Danube:Future network) had to be created to cope with the challenges of the wicked problems captured in the "Grand Challenges". They might come to understand that what were, on the surface, technological innovations such as windparks, would not have been possible without changes in governance, new regulations cast into laws and regulations.

They might note that the Humanities and Social Sciences, despite their obvious importance, were latecomers to sustainable development issues. But in the end, it might turn out in retrospect, developing cultural heritage could be considered key to a meaningful life for many and hence, a key to a less material-intensive, peaceful and diverse, sustainable society. In short, the researchers of the future might be able to see the structural similarity between the engineering marvels of the $19^{\text {th }}$ century, and today's ecologies of innovation for sustainability.

\section{References}

Alexander, Th.A. "Educating the Democratic Heart: Pluralism, Traditions and the Humanities", Studies in Philosophy and Education 13, 243-259, 1994/95.

Ardeleanu C. "International Trade and Diplomacy at the Lower Danube: The Sulina Question and the 
Economic Premises of the Crimean War (18291853)", Editura Istros, 2014.

The Australian Academy of the Humanities "The Humanities and Australia's National Research Priorities", Report prepared for DEST (Dept. of Education, Science and Training), 2003.

Council of Europe "The Role of Culture and Cultural Heritage in Conflict Prevention, Transformation, Resolution and Post-Conflict Action", AT(2010)397 rev.1 [Online], http://www.coe. int/T/DG4/cultureHeritage/News/CultureReconciliation en.pdf, 2011 (Accessed September 3, 2017).

Giblin, J.D. "Post-conflict heritage: symbolic healing and cultural renewal", International Journal of Heritage Studies, 20(5), 500-518, 2014.

Holm, P. and Winiwarter, V. "Climate change studies and the human sciences", Global and Planetary Change, 156, 115-122, 2017.

Huutoniemi, K. "Interdisciplinarity as academic accountability: Prospects for quality control across disciplinary boundaries", In Social Epistemology 2016 (30.2), 163-185, 2016.

Krainer, L. and Winiwarter, V. „Die Universität als Akteurin der transformativen Wissenschaft. Konsequenzen für die Messung der Qualität transdisziplinärer Forschung", GAIA, 25/2, 110116, 2016.

McKelvey, M. "Using Evolutionary Theory to Define Systems of Innovation", In C. Edquist (ed), Systems of Innovation. Technologies, Institutions and Organizations. London and New York: Routledge, 200-222, 1997.

Rittel, H.W. and Webber, M.M. "Dilemmas in a General Theory of Planning", Policy Sciences, 4(2), 155-169, 1973.

Vervloet, J.A., Nijman, J.-H. and Somsen, A.J. "Planning for the future; towards a sustainable design and land use of an ancient flooded military defence line", Landscape and urban planning, 70(1), 153-163, 2005.

Wissenschaftlicher Beirat der Bundesregierung Globale Umweltveränderungen (WBGU) „Welt im Wandel. Gesellschaftsvertrag für eine Große
Transformation, Hauptgutachten, Berlin" [Online], http://www.wbgu.de/hauptgutachten/hg2011-transformation/, 2011 (Accessed September 3, 2017).

Winiwarter, V. "The 2013 DIAnet International School, its aims and principles against the background of the sustainability challenges of the Danube River Basin", In S. Brumat and D. Frausin (eds), DIAnet International School Proceedings 2013, 19-41, [Online], http://www.openstarts. units.it/dspace/handle/10077/9336, 2013 (Accessed September 3, 2017).

Winiwarter, V. "Designing trans-disciplinary projects for sustainable development”. In S. Brumat and C. Macchia (eds), DIAnet International School Proceedings 2014, 45-59, [Online], http://www.openstarts.units.it/dspace/handle/10077/10489 , 2014 (Accessed September 3, 2017).

Winiwarter, V. “The Many Roles of the Dynamic Danube in Early Modern Europe: Representations in Contemporary Sources", In J. Costlow, Y. Haila and A. Rosenholm (eds) Water in Social Imagination: from Technological Optimism to Contemporary Environmentalism, Leiden: Brill Rodopoi, 49-76, 2017. 


\title{
Understanding Ecosystem Dynamics for Designing Socio-Economic Systems: Following Nature's Way
}

\author{
BRIAN D. FATH
}

\section{Introduction}

The topic of our Alpbach session was on The cycle of innovation and its ecology. As a systems ecologist, my lens is to see the world through interacting ecological processes and relations. Careful analysis of ecological systems has revealed a consistent set of processes and attributes that stem largely from first principles of thermodynamics, information theory, and hierarchy theory (Jørgensen et al., 2007). These concepts form the basis of referring to ecosystems as complex adaptive and hierarchical systems (Patten et al., 2002).

Ecological systems grow and develop, using the available energy to build diverse and complex structures (Fath et al., 2004). We refer to the built structures as gradients indicating that the system has moved further from a baseline; in energetic terms, the system is said to move away from thermodynamic equilibrium. This gradient formation can be measured by the total energy flowing through the system, the total energy stored in the system, the increase in cycling, the decrease in entropy generation, or a number of other ecological goal functions (Fath et al., 2001). This ecological perspective of self-organizing complexity adds a new level of introspection for the development of systems regarding both their possibilities and constraints. Previously, in both ecology and social systems, much emphasis has been placed on the dissipation or exploitation of these gradients, for example, Newton's iconic apple falling from the tree which inspired the laws of gravity. In a closed system, the existing gradients, in this case against gravitational forces, will eventually come to equilibrium such that the apple falls from the branch to the ground, not the other way around. Of course, one could assume oppositional physical forces, such as a strong gust of wind which could in theory pick up an apple on the ground and lift it to a branch, or flood water that floats the apple above the ground to the level of the branch, but in each of these cases there was an external energy source (solar, used for general circulation or to drive the hydrological cycle), meaning that the system was open and not closed. Also, in each case although the physical distance of the gravitational gradient was overcome that does not mean that the apple becomes re-animated or reconnected to the tree. More to the point, ecologically, the tree was able to construct the gradient in the first place by overcoming gravity and lifting the necessary ingredients from the soil (water, nutrients, etc.) to the branch and concentrated those elements in the apple. Again, this was accomplished as an open system, this time the solar energy used for both evapotranspiration and also in photosynthesis. Some of this energy is stored in the biochemical bonds and genetic information of the apple and some is stored in the elevated position of the apple.

What is special to recognize is that the self-organizing aspects of the species in the ecosystem and of the ecosystem itself move against dissipative forces to construct order and organization in the form of new gradients through growth and development. Assuming that natural ecosystems respond to the prevailing conditions in ways that foster this gradient construction, when applying the principles to socioeconomic systems, the question arises: What are the right conditions to promote growth and development of new ideas and innovation?

The great challenges we face with resource extraction and waste generation leading to unsustainable patterns can be traced first and foremost to a break 
from nature's cycles. We have much to learn from the innovation and wisdom of nature. In particular, there are three main messages I intend to convey in this article: 1) the biophysical world imposes constraints on all system growth and development, but these limits do not need to be seen as negative; 2) the dynamic cycle of growth and development in ecosystems is matched by a cycle of decay and dissolution, which provides important openings for new system developments; and, 3) system resilience can be viewed in terms of navigating this dynamic cycle (growth $\rightarrow$ conservation $\rightarrow$ dissolution $\rightarrow$ reorganization) and the required competencies for each stage need to be cultivated in each of the preceding stages, thus a holistic model of the system dynamics is needed. Each of these three points will be addressed in turn below.

\section{Flourishing within limits}

In 1972, scientists supported under the umbrella organization called the "Club of Rome" issued a dire and urgent message titled Limits to Growth (Meadows et al., 1972). Their work was one of the first attempts to use systems dynamics models to make an integrated model at the global scale of large driving factors such as human population, agricultural production, industrial production, natural resource availability, and pollution. They found that under business as usual conditions the current socio-economic system would collapse through a combination of overpopulation, limited resources, and environmental pollution. Even scenarios that assumed unlimited resources resulted in system collapse due to human population growth and subsequent build-up of environmental pollution - a bird cannot continue to foul its own nest. The only stablescenario relied onastablepopulation, transition to renewable resources at a rate the matched replacement, and with investment in pollution control technologies. Although, this scenario should have provided a road map as a way forward, their study had little impact on decision makers and economists. The mere idea of admitting limits was off putting enough to some groups that the report was largely dismissed rather than a blueprint as it should have been. Forty-five years later the population continues to climb (although at a slower rate), resource utilization increases, and absolute pollution (including GHG) emissions are at all-time highs. What was missing from the report was the clear message that ecosystems grow and develop in the face of limits - they are limited on the input side by the rate of available resources determined by the biogeochemical cycles of that specific regions' climate, geology, hydrology, latitude, altitude, etc. They are limited on the output side by the rates of decomposition and finding others to utilize their waste again to avoid fouling their own environment. But, in spite of these constraints, ecosystems grow and develop into complex, diverse, hierarchical, adaptive, interactive systems as mentioned above. One could say that ecosystem flourish within these limits. This was the message of a recent book (Jørgensen, et al. 2015) to recast the original Limits to growth model in light of principles of ecological organization. In that book, we identified 14 basic properties of ecosystems (table 1) most dealing with fundamental aspects of energy exchange and utilization. Results indicated that simple rules such as better resource utilization (the three R's: reduce, reuse, recycle), transition to renewables, focus on building gradients (in terms of work energy capacity), and investment in education and science that bring innovation will provide substantially better outcomes than business as usual. It is possible to flourish within the limits to growth. A similar message was conveyed by eminent systems thinker Jane Jacobs when she said "Natural principles of chemistry, mechanics and biology are not merely limits. They're invitations to work along with them" (Jacobs, 2000, p. 12). And, more recently in the environmental film This Changes Everything, Indian Environmentalist Sunita Narain framed the situation optimistically by saying, "There are limits. Let's celebrate the limits, because we can reinvent a different future." This message of flourishing within limits is beginning to resonate in the environmental community, but first it requires an acknowledgement of the limits, and second a good understanding of how natural systems operate. 
Tab. 1: 14 Ecosystem properties identified in systems ecology literature. For a more thorough description of them see Jørgensen et al. 2015
1. Ecosystems conserve matter and energy
2. There are no trashcans in Nature
3. All processes (in nature and society) are irreversible
4. All life uses largely the same biochemical processes
5. Ecosystems are open systems and require an input of work energy to maintain their function
6. An ecosystem uses surplus energy to move further away from thermodynamic equilibrium
7. Ecosystems use three growth and development forms: 1) biomass, 2) network, 3) information
8. Ecosystems select the pathways that move it most away from thermodynamic equilibrium
9. Ecosystems are organized hierarchically
10. Ecosystems have a high diversity in all levels of the hierarchy
11. Ecosystems resist (destructive) changes
12. Ecosystems work together in networks that improve the resource flow utilization
13. Ecosystems contain an enormous amount of information
14. Ecosystems have emergent system properties

\section{Ecosystem dynamics}

Ecological succession is the process by which an ecosystem inhabits a new area and fills it with life and life-adapted environments. During the early stages, there is not much biomass and therefore not much primary production to capture the available solar energy; gross production is low. However, the demands of the simple system are modest so the maintenance costs, in terms of respiration, are also low. During this early stage, photosynthetically-active plant material increases faster than the maintenance costs thus providing substantial net production that can be used to further grow the system. This creates a positive feedback loop such that growth promotes more growth. Again referring to Jane Jacobs' insight, she described this situation as "The ensemble itself made the environment rich by expanding" (Jacobs, 2000, p. 49). A simple balance formula describes the process:

$\mathrm{Pn}=\mathrm{Pg}-\mathrm{R}$

Where Pn is net production, Pg is gross production, and $\mathrm{R}$ is respiration. This is a standard accounting equation similar to Profit equals Revenue minus
Costs. During the entire course of succession, the net production increases in the early stages, but then reaches a maximum and begins to decline, effectively dropping near zero (figure 1) even at the point when the system is most massive in terms of biomass and most complex in terms of diversity and connectivity. This decline in net production occurs because once the ecosystem matures it reaches a stage where there is no additional space for photosynthetic capture (referred to as maximum leaf area index), and gross production levels off. However, the respiratory demands of non-photosynthetic materials continue to increase (roots, reproductive structures, stems, trunks, herbivores, carnivores, decomposer, etc.) as they all rely on the original solar energy captured through photosynthesis. In this later successional stage, maintenance costs approach gross production and net production - energy available for new growth - is minimal. It is important to note that at this stage where input of solar radiation and output of respiration to support the ecosystem are balanced, the system is not static or failing. There is a constant flow pushing through the system. To reiterate the point above, the system at this stage has a high level of diversity, complexity, organization, information, stored biomass, and energy throughflow, but it is no longer growing. 
Fig. 1: Changes in gross production $\left(P_{f}\right)$, net production $\left(P_{n}\right)$, respiration $(R)$, and biomass $(B)$ through ecological succession. Green bands represent period of increasing availability of net production during early stages of growth and development and red bands show a decline and disappearance of net production as all gross production is used for respiration (modified from Odum, 1969, reprinted with permission).

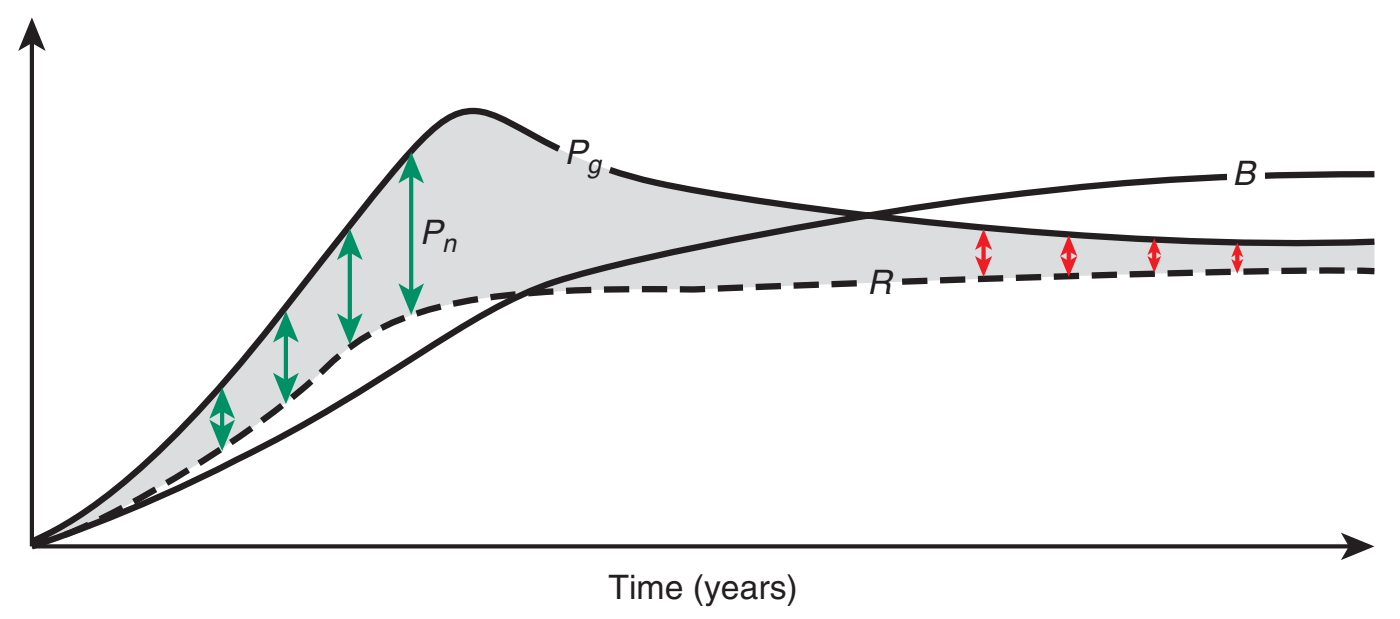

This transition from early growth stages to later stages in ecosystems is perhaps one of the most important insights to apply to socio-economic systems. In nature, there is a shift during later mature stages to focus not on growth but on maintaining the complex system functions. Why are we in socio-economic systems fixated on growth? If the goal is growth, then there are two ways to continue, either by putting in more input or by squeezing more out of the existing energy through efficiency gains. The former was easy to implement when new resources were plentiful. Extensive and intensive agriculture are examples of the former and latter approaches.

Regarding energy management in human societies, in terms of capturing solar flow, historically this was carried out through cultivation of specific species that produced a proportionally large amount of edible or otherwise useable biomass (grains, fruits, tubers, fiber, etc.). Scarcity brought pressure for innovation to increase this production through soil, water, and nutrient management. While agriculture represented a way to capture annual flow of solar energy, just as important to human survival and well-being was utilization of exosomatic energy in biomass (mostly wood) for cooking and heating, which is solar energy stored at a decadal or century-scale. At a national scale, energy availability constrained productivity, leading to expansionary policies: more land equated access to more solar energy flows (of course, it was even more "efficient" to capture the energy already concentrated in another society's possessions, parti- cularly gold and people, but that is a different, more sordid, story). More recently, during the past few centuries, the utilization of fossil fuels (solar energy stored on a geological time scale) primed the global growth machine with immense new volumes of energy resources as input. These fossil fuels led to the explosive growth witnessed during the industrial revolution. The problem with relying on ever greater supplies of input to generate growth is obvious, because the energy demands can outpace supply, not to mention the human health and environmental consequences of acquiring, processes, and utilizing those energy sources. The ecological solution would be to transition away from a growth orientation toward one of maintenance, with a longer time horizon. However, even a complex, adaptive, stable ecosystem does not persist forever as there are disturbances over many scales that eventually reset the system back to more simple conditions. In an ecosystem, these disturbances can appear as fires, floods, volcanoes, hurricanes, climate change, etc.

In this manner, we consider that the growth and conservation stages of ecological development are only part of a larger cycle that includes dissolution from disturbances and reorganization, which initiates another growth cycle (figure 2). The four stage adaptive cycle (Holling, 1986) provides a useful framework for investigating the long term dynamics of any system. 
Fig. 2: Adaptive cycle showing four stages of Grow, Conservation, Decline and Reorganization (reprinted with permission from Burkhard et al., 2011).

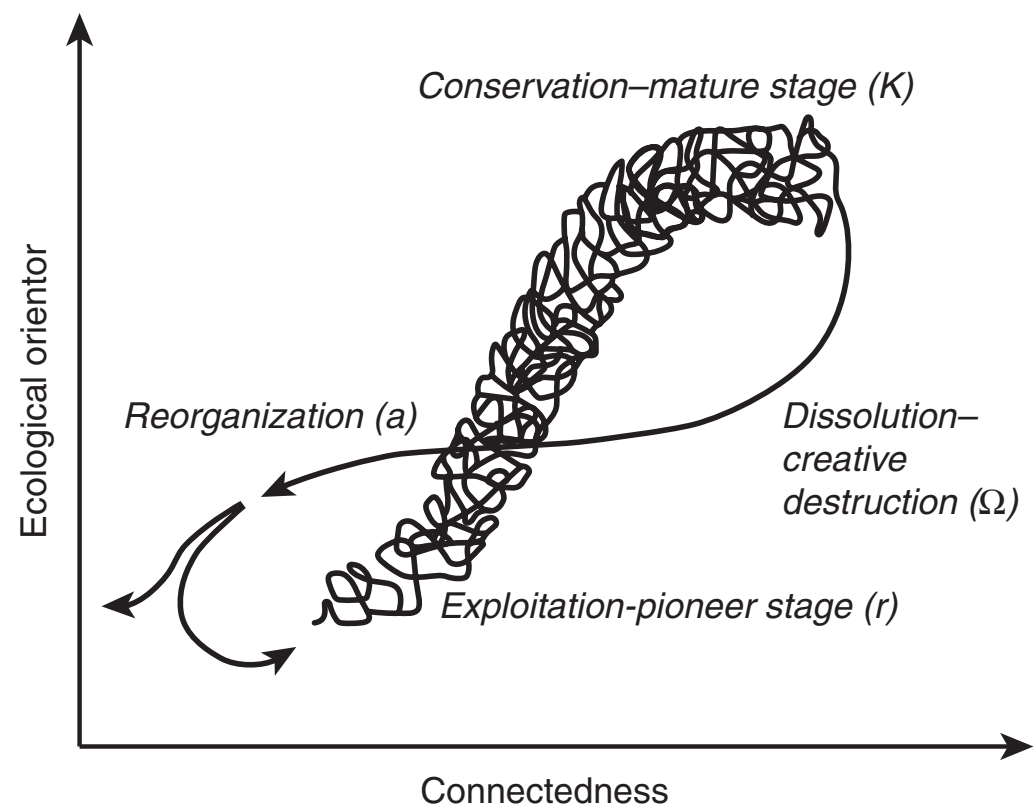

In our discussion of innovation, it is useful to point out that a system has the highest development potential when it is just beginning the growth stage. At this point, the system configuration is still a blank slate waiting to be filled (given the environmental conditions and constraints). Once a system gets established, those agents present further constraint and influence the successive actors that enter the stage. A form of path-dependent development obliges the system along a particular direction that then excludes other possibilities. In other words, once a certain path is followed, other pathways are inaccessible. This is easy to imagine in everyday life cases. For example, imagine having a simple blank piece of paper. While the information content on the blank paper is zero, its development potential is highest as it literally has infinite possibilities (within the physical constraints of paper). As one starts to fill the blank space, the information on the page increases, but its potential space decrease. Perhaps one writes a poem, or mathematical equations, or a grocery list, or sketches the birds outside the window. The choice of one of these precludes the others. Thus, we can imagine that the overall development potential decreases during the realization of one particular outcome (figure $3)$. Once the paper is erased clean it could be availa- ble to start a new development pathway. Depending on its ability to be wiped clean, traces of the previous use leave a lasting shadow on the paper.

Another example could be a bright first year student at the university - the world is her oyster - with so many possibilities to develop talents and influence the world. The reality is that disciplines must be chosen and selections must be made that lead to a specific profession. Investing time in classes in medicine, takes away from classes that could be spent in law or physics or art history. Of course, there are individuals that have multiple specialties but there are constraints - such as only so many hours in the day. One cannot learn everything, especially given the rate of knowledge generation in today's world. In fact, this long-term upward trend in knowledge generation is a direct result of the specialization. Therefore, the scale of analysis matters. For an individual, there is an inverse relation between specialization and overall development potential, but society as a whole benefits through some degree of specialization because the high diversity of individuals working together as experts in their respective fields. Again, there is a complimentary analogy to an ecosystem that contains high levels of diversity and specializati- 
on on the local level to give an overall more complex functioning system.

For a socio-ecological example of the trade-off between development and development potential, land use follows a similar constraining pathway. A forested area may be protected and maintained or cleared for agriculture or the site of a new city. The particular configuration squeezes out other possibilities for a time being (editorial aside: although there may exist fine-grained variations - house in agricultural area or urban gardens - in general these dalliances decrease the overall performance of one type over the other). As is the case through the long arc of history, the landscape gets written on over and over again. This is evident in the long term use of the landscape which becomes a palimpsest with historical and cultural remnants.

The case that development potential decreases during development may not be immediately intuitive, but fits in the adaptive cycle framework of growth $\rightarrow$ development $\rightarrow$ conservation $\rightarrow$ collapse $\rightarrow$ reorganization. This is why the collapse stage has been referred to as "creative destruction". However, there is a countervailing force that should be mentioned which is the idea that development begets co-development. Again, I maintain this is a scale issue, that within a broader scale, development is limited but within the boundaries new opportunities and ideas emerge from the interactions with the development that has already occurred. The presence of one opportunity opens the possibility for others. The reinforcement of one idea on another forms a positive feedback cycle, that under the right conditions may become an autocatalytic cycle, bootstrapping the system such that these interlocking ideas move it further and further from its place of origin. There is a similarity of application of autocatalytic cycles one sees in the ecological growth and development mentioned above during succession that results in increased biomass, diversity, complexity, and network structure. This area of research into autocatalytic cycles (Cazzolla Gatti, 2017; Ulanowicz, 2003; Ulanowicz, 2008) is providing fresh insight into the ways that nature, as well as socio-economic systems, behaves.

\section{Resilience}

One could say that the goal of the system, of a resilient system, is to be able to successfully navigate all stages of this adaptive cycle from growth $\rightarrow$ development $\rightarrow$ conservation $\rightarrow$ collapse $\rightarrow$ reorganization (Fath et al., 2015). In an unhealthy system, there are

Fig. 3: Inverse of the adaptive cycle shows that development potential declines with increasing (reprinted with permission from Burkhard et al., 2011).

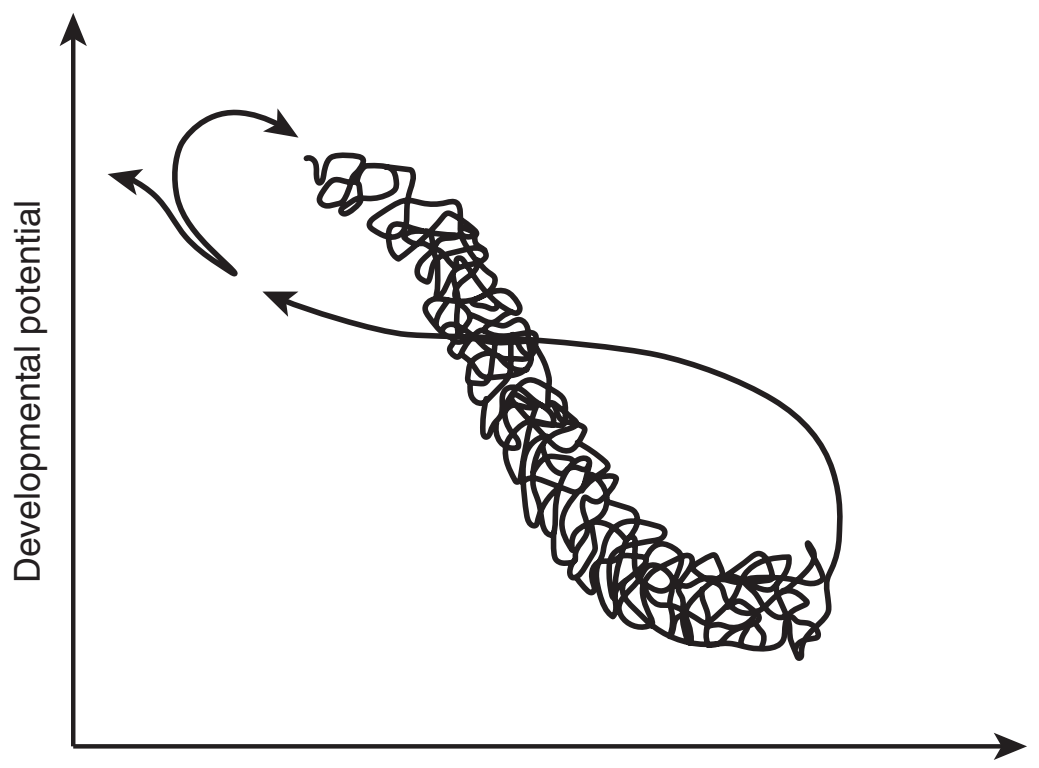

Connectedness 
pathologies that inhibit it from either entering into the next stage - usually in terms of lacking some resource or readiness - and also forces that resist the system to exit to the next stage, through dominance of status quo (table 2). Recognition that all stages are interlinked and necessary is important to keep a healthy and innovative system. For example, the transition from the growth and development stage to conservation stage occurred in nature when more energy was being used for maintenance and less was available for net production.

A shift away from a growth oriented paradigm to a cyclical one would be more in tune with nature. A case could be made that much of humanity survived and thrived within this rhythm, with an emphasis on time, work, rites and rituals, marking the cycle with touchpoints, closure and new beginnings, but always on the same basic trajectory. Another important insight that becomes apparent when considering the resilience of a system over the entire adaptive cycle is that the capacities and competencies that are needed to continue along this cycle are developed during each stage, not just for the immediately upcoming stage but for all of them. Therefore, during system development it is necessary to have in mind future positions along the cycle. For example, in order to escape the poverty trap (r-stage), positive feedbacks must be kick-started during this stage, as well as recognition of bilateral information flows (information flowing in both directions of system hierarchy) for the K-stage, emergent leadership developed during the $(\Omega)$ phase and adaptive capacity cultivated during the a-stage to be able to recognize learning experiences and use the opportunity to make adjustments to behavior (see Fath et al., 2015 for specific details of each stage and the related competencies). Recollection and appreciation of functioning in and along the ongoing cycle would help to keep all the stages in focus.

Tab. 2: Pathologies that obstruct passage through the complete systems cycle either by inhibiting entry to the next stage or preventing exit from the current stage.

\begin{tabular}{|l|l|l|}
\hline $\begin{array}{l}\text { Growth } \\
\text { r-stage }\end{array}$ & Entry & Exit \\
\hline $\begin{array}{l}\text { Poverty trap - no activation energy, } \\
\text { no scaling }\end{array}$ & $\begin{array}{l}\text { Overshooting (,forever young"), relentless re- } \\
\text { Source acquisition }\end{array}$ \\
\hline $\begin{array}{l}\text { K-stage } \\
\text { Dissolution }\end{array}$ & $\begin{array}{l}\text { Lack of internal complexity (right } \\
\text { buffers, redundancies, connections) }\end{array}$ & Perpetuation of status quo through cannibalism \\
\hline $\begin{array}{l}\text { Reorganization } \\
\boldsymbol{\alpha} \text {-stage }\end{array}$ & $\begin{array}{l}\text { Subsidize rigid systems } \\
\text { Self-victimization mentality }\end{array}$ & Inability to improvise of connection to the outside) \\
\hline
\end{tabular}




\section{Conclusions}

Innovation has helped to promote the growth and pace of the cycle, but it has also brought new pressures and a removal of asking big questions of why we do certain things. There is still much to be learned from nature at a technical level (specific compounds, biofilms, structures, etc.) and at a systems level (sustainable organization, synergies). The differences between nature and socio-economic systems appear large these days, but both rely on the same basic principles of thermodynamics and self-organization of complex, adaptive, and hierarchical processes. Some of these key differences are given below:

1. Ecosystems operate over the long term at the mature phase $(\mathrm{K})$.

2. Ecosystems are very efficient at supporting a great amount of structure for a given amount of production (Biomass to productivity ratio high is in mature ecosystems).

3. Current economics emphasize the creation of increased production ( $r$ ) rather than biomass maintenance, which is an immature phase according to ecological succession.

4. Current economics are unprepared and resistant to cyclical changes $(\Omega \& \alpha)$.

In conclusion, this over-emphasis on the growth stage of an adaptive cycle at the expense of the other stages, leads to much of the tension between social and natural systems. We can do a much better job at learning from innovations in nature in order to move toward management that promotes sustainable solutions.

\section{References}

Burkhard, B., Fath, B.D. and Müller, F. "Adapting the adaptive cycle: Hypotheses on the development of ecosystem properties and services", Ecological Modelling, 222, 2878-2890, 2011.

Costanza, R. and Jorgensen, S.E. (eds) "Understanding and Solving Environmental Problems in the 21st Century: Toward a New, Integrated Hard Problem Science". Amsterdam-Boston-London: Elsevier, 2002.
Cazzolla Gatti, R., Hordijk, W. and Kauffman, S. "Biodiversity is autocatalytic", Ecological Modelling, 346, 70-76, 2017.

Fath, B.D., Patten, B.C. and Choi, J.S. "Complementarity of ecological goal functions", Journal of Theoretical Biology, 208(4), 493-506, 2001.

Fath, B.D., Jørgensen, S.E., Patten, B.C. and Straškraba, M. "Ecosystem growth and development”, Biosystems, 77, 213-228, 2004.

Fath, B.D., Dean, C.A. and Katzmair, H. "Navigating the adaptive cycle: an approach to managing the resilience of social systems", Ecology and Society, 20(2), 24, 2015.

Holling, C.S. “The resilience of terrestrial ecosystems: local surprise and global change", In W.C. Clark and R.E. Munn (eds) Sustainable development of the biosphere. Cambrindge, UK: Cambridge University Press, 292-317, 1986.

Jacobs, J. “The Nature of Economies”. New York: Random House, 2000.

Jørgensen, S.E., Fath, B.D., Bastianoni, S., Marques, J.C., Müller, F., Nielsen, S.N., Patten, B.C., Tiezzi, E. and Ulanowicz R.E. "A New Ecology: Systems perspective”. Amsterdam: Elsevier, 2007.

Jørgensen, S.E., Fath, B.D., Nielsen, S.N., Pulselli, F., Fiscus, D. and Bastianoni, S. "Flourishing Within Limits to Growth: Following nature's way”. Abingdon: Routledge, 2015.

Odum, E.P. “The Strategy of Ecosystem Development”, Science, 164(3877), 262-270, 1969.

Patten. B.C., Fath. B.D. and Choi, J.S. "Complex adaptive hierarchical systems-background”, In R. Costanza and S.E. Jorgensen (eds) Understanding and Solving Environmental Problems in the 21st Century. London, England: Elsevier Science Ltd., 41-94, 2002.

Ulanowicz, R.E. "On the ordinality of causes in complex autocatalytic systems", Annals of the New York Academy of Science, 988, 154-157, 2003.

Ulanowicz, R.E. "Autocatalysis”, In S.E. Jørgensen and B.D. Fath (eds) Systems Ecology. Vol. 1 of Encyclopedia of Ecology. Oxford: Elsevier, 288-290, 2008. 


\title{
Summary - The Cycle of Innovation and its Ecology On Therapists, Entrepreneurs, Bureaucrats and Fatalists and their Role in the Process of Creative Deconstruction
}

\author{
HARALD KATZMAIR
}

This edition of KIOES represents more than a loose collection of authors accidentally linked though the attendance of a joint break-out session at Forum Alpbach 2016: The papers are interconnected though a shared interest in exploring the homologies between structural and diachronic (historical) dynamics in nature and culture, and the key role of diversity (variety) as outcome and catalyst of the emergent process of (social) innovation. By crossing the lines between models from ecology, resilience science, cultural theory, social ecology and environmental history the papers should be perceived as an "interim report" in an ongoing effort to gain new perspectives and insights in explaining the origins and structural conditions of (social) innovations. The contributions in this edition demonstrate that transversal scientific boundary work offers a prolific context for raising new questions, inspiring ecologists and cultural scientists alike to see their own field with fresh eyes.

\section{Homologies}

Over the last few years "Ecologies" has become one of the most frequently used buzz-words in technology, innovation policy and corporate business (Hwang and Horowitt, 2015). Used in the majority of cases as bare analogy for building and hosting technological platforms, the cognitive gap in the interpretation of the word "ecologies" between entrepreneurs and policy makers on the one side and new ecologists (Jørgensen, 2007) on the other, could not be larger. The organization of the break-out session at Forum Alpbach 2016 was driven by the notion that innovation policy might profit tremendously from recognizing the striking structural homologies between ecosystem dynamics and the relational morphologies of highly innovative and successful socio-technological networks.

The process of social and technological innovation follows a well-known pattern, that was condensed by the Austrian economist Joseph Schumpeter in his iconographic metaphor of innovation as an ongoing cycle of "creative destruction". There is a significant homology between the process of invention $\rightarrow$ growth $\rightarrow$ saturation $\rightarrow$ deconstruction in the technological innovation cycle and the eco-cycle in nature (Gunderson, 2002), a homology regards the formative role of total energy throughput (flow and storage of energy in ecosystems/flow and accumulation of financial capital), network structure (chemical autocatalytic cycling in nature/structural folds in social networks), and of quality of information (genetic diversity and edge effects in ecosystems/cultural complexity and diversity of narrative frames in societies).

Regarding the latter, blending models from resilience theory, ecosystem science (Fath et al., 2015) and cultural theory (Thompson, 2008) it can be shown that different stages of the innovation cycle (invention $\rightarrow$ growth $\rightarrow$ saturation $\rightarrow$ deconstruction) require different types of "players" or "characters" to make the cycle work: an individualistic culture of the "doer" at the start-up stage, a hierarchical culture of the strategic manager for growth and scaling, an egalitarian codex to navigate the dramatic turbulences of destruction, an autonomist culture for pioneering and radical innovation, a culture of healing, let go of old, dysfunctional knowledge and practices. In our western knowledge system, these different cultures go along with different institutions: large organizations, 
such as corporations or universities dominated by hierarchical mindsets, NGOs and community initiatives driven by egalitarian codes, start-up communities characterized by individualistic world views, artistic and scientific communities inspired by the idea of autonomy and independence. Models from the field of computational thinking (Kowalski, 2011) can explain how different levels of local/global and informed/uninformed search strategies are linked with these different cultural frames and regimes of assessing, judging, evaluating, organizing and disorganizing our world.

\section{Responsive variety}

With different institutions, different modes of knowing and problem solving come along. Different frames are like looking through different prisms at the world, with each being characterized by its specific bending of the light and its specific shadow of not-knowing. Each of the modes of knowing finds its epistemological niche: its place to thrive in the shadow of the not-knowing of the other frames. To use an example from cultural theory, it is the egalitarian that thrives in the shadow of what the hierarchist actively rejects or cannot see through his cultural lens and vice versa.

Attributes, such as excellence, utility, impact, resonance, beauty, empathy and transcendence, offer radically different scales and narrative frames to measure the outcome of something that is perceived as being "innovative". The idea that there is just one scale (as increase in effectiveness or efficiency, or acceptance among customers) is based on a limited and limiting understanding of how the new gets born and of how it overcomes the resistance of established players. Inventors and early adopters are frequently driven more by aesthetic or altruistic values (doing good) than by the prospect of economic gain (doing well). There must be meaning as fuel of innovation, capital is not enough to spark the fire.

The core hypothesis of our break-out session followed the idea, that the linked diversity of different values and knowledge cultures across different scales (Gunderson, 2004; Alexander, 2004; Salingaros, 2009) is building a cultural and intellectual gradient that enhances the responsive variety (resilience) of an innovation system and is mandatory for sustainable performance. Taking up Google's (Schmidt, 2015) mantra that those organizations who define themselves through their product or technology will die, and only those will survive who define themselves through their platform or ecology, the goal of the break-out session was to discuss a generalized model of knowledge (including its different cultures of searching for solutions) that should inhabit an innovation ecology in order to be successful. Speakers from the field of policy making, computational thinking, resilience theory, cultural theory, and citizen and community science exchanged perspectives on the dimensions and composition of an innovation landscape that thrives even in critical situations. The role of the scientist, the hacker, the visionary, the entrepreneur, the bureaucrat, the therapist, the community organizer and even the "trouble maker" was determined, and the likelihood of the hybridization of these roles due to emergent social dynamics for example in the form of the "science entrepreneur", "facilitatist" or the "community entrepreneur" - was discussed (Winiwarter, 2017, this edition).

The session also addressed the practical question of the new frameworks and policy measures that are required to strengthen the responsive variety of our innovation systems. If the horizontal connectedness of an innovation system - the collaboration across different regimes of knowing - is to be strengthened, a completely new set of funding instruments will be required. The specific role of charitable foundations to fund cross-scale-science, along with the need for special governmental programs or institutional manifestations to strengthen the field of open innovation and citizen/community science, was discussed.

\section{Renaissance thinking}

The findings were linked with the general topic of Forum Alpbach 2016 - the quest for the possibility of and framework for a new Enlightenment. If scientific evidence shows that constellations with multiple and different regimes of organizing, each with its supporting mode of knowledge, bring forth more resilient and robust results in terms of learning and development - if it can be proven that an innovation landscape with a diversified portfolio of scales is more effective in the long run - then this would have an immediate impact on our understanding of the role of academia and other institutions that create and provi- 
de knowledge. It would give strong support to those who stress the importance of measuring and evaluating knowledge not only in terms of "excellence" but also on the scales of "utility", "impact", "resonance" and even "beauty". It would also give strong support to those who are arguing for stronger cross-institutional collaboration and for a new transdisciplinary mindset of Renaissance thinking to overcome fragmentation and incoherence.

A new Enlightenment, taking its cue from William Blake's dissatisfaction with "Newton's sleep", and his embracing of what he called "a fourfold vision", would seek out and grant legitimacy to a range of institutional settings, each with its distinctive mode of knowing.

The necessary ambiguity that goes along with such an understanding of different sources and frames of (scientific) knowledge corresponds well with the reality of participatory co-management, open innovation, hackathons, design thinking, community and citizen science and action research. It also advocates strongly for an open, inclusive and cohesive society that strives to overcome fragmentation and overspecialization and that is able to mobilize and nurture the potential of those who feel fatalistic and excluded. To promote diversity and tolerance of ambiguity is thus not a moral postulate, it is a vital matter of strength and possibility for sustainable survival, it is the decisive capacity, capability and culture that we have to establish in order to thrive in a world of dancing and cracking landscapes.

\section{Acknowledgements}

I would like to thank the OeAW for the openness and generous support to publish the results of this substantial interdisciplinary collaboration, manifested in the articles by Brian Fath, Michael Thompson and Verena Winiwarter et.al. In a scientific world characterized by a deep divide between different scientific cultures, journals such as KIOES Opinions that bring together social scientists, cultural scientists and natural scientists in one and the same edition are not only a pleasant exception, they nurture the opportunity for new combinations and real scientific progress based on the productive encounter of otherwise separated disciplines.

\section{References}

Alexander, C. " $A$ Vision of a Living World: The Nature of Order: An Essay of the Art of Building and the Nature of the Universe". Berkeley: Center for Environmental Structure, Book 3, 2004.

Fath, B.D., Dean, C.A. and Katzmair, H. "Navigating the adaptive cycle: an approach to managing the resilience of social systems", Ecology and Society, 20(2), 24, 2015.

Gunderson, L.H. and Holling C.S. "Panarchy: Understanding Transformations in Human and Natural Systems". Washington-Covelo-London: Island Press, 2002.

Hwang, V. and Horowitt, G. "The Rainforest: The Secret to Building the Next Silicon Valley". Los Altos Hills: Regenwald, 2012.

Jørgensen, S.E., Fath, B.D., Bastianoni, S., Marques, J.C., Müller, F., Nielsen, S.N., Patten, B.C., Tiezzi, E. and Ulanowicz, R.E. "A New Ecology: Systems perspective”. Amsterdam: Elsevier, 2007.

Kowalski, R. "Computational Logic and Human Thinking: How to be Artificially Intelligent". Cambridge-New York-Melbourne: Cambridge University Press, 2011.

Salingaros, N.A. "A Theory of Architecture". Solingen: Umbau Verlag, 2009.

Schmidt, E. “How Google Works". New York-Boston: Grand Central Publishing, 2014.

Thompson, M. "Organizing and Disorganizing: A Dynamic and Non-linear Theory of Institutional Emergence and its Implications". Axminster: Triarchy Press, 2008.

Winiwarter, V., Haidvogl, G. and Brumat, S. "Cocreative innovation for sustainability: Creating robustness in a rapidly changing world through inter- and transdisciplinary research", In V. Winiwarter (ed), KIOES Opinions 6, 20-26. Vienna: Austrian Academy of Sciences, 2017. 


\section{Author biographies}

Stefano Brumat is a project manager in European funded projects and in particular attends to the development and management of EU-financed regional and transnational projects. As project administrator of the EUSDR PA7 flagship project "Danube:Future" since 2013, he participates in budget administration, providing analysis, keeping records, and forecasting financial performance. Furthermore he organized three editions of the DIAnet International Schools in Gorizia (I), training school for junior researchers from the Danube Macroregion. He currently works at the University of Modena and Reggio Emilia (I), Department of Biomedical, Metabolic and Neural Sciences.

E-mail: stefano.brumat@unimore.it

Brian D. Fath is Professor in the Department of Biological Sciences at Towson University (Maryland, USA) and Research Scholar within the Advanced Systems Analysis Program at the International Institute for Applied Systems Analysis (Laxenburg, Austria). His research is in the area of systems ecology and network analysis applied to the sustainability and resilience of socio-ecological systems. Prof. Fath has published more than 150 research papers, reports, and book chapters. He is also Editor-in-Chief for the journal Ecological Modelling. Prof. Fath was a Fulbright Distinguished Chair at Parthenope University of Naples, Italy in spring 2012, and recipient of the Prigogine Medal in 2016.

E-mail: bfath@towson.edu

Gertrud Haidvogl is senior scientist at the Institute of Hydrobiology and Aquatic Ecosystem Management, University of Natural Resources and Life Sciences Vienna (BOKU). She is specialized in historical ecology and environmental history of rivers. Her research deals especially with the socio-ecological development of riverine landscapes, fish and fisheries and the bearings of past human interventions on present river management. The Danube is a major site of her work since more than ten years. Gertrud Haidvogl is deputy-coordinator of "Danube:Future - A sustainable future for the Danube River Basin as a challenge for the interdisciplinary humanities". E-mail: gertrud.haidvogl@boku.ac.at

Harald Katzmair is social scientist and philosopher, and founder and director of FASresearch, a Social Network Analytics \& Strategies firm located in Vienna. Over the last two decades, he has developed a unique and proprietary set of tools and technologies to empower decision makers in the areas of social network dynamics, robust decision making, story telling, stakeholder engagement and participatory impact analysis as well as innovation and resilience. Harald Katzmair serves as vice-president the foundation "NEIN ZU KRANK UND ARM" in its endeavor to overcome illness and poverty in Austria and is a member of the supervisory board of the Austrian Science Fund (FWF).
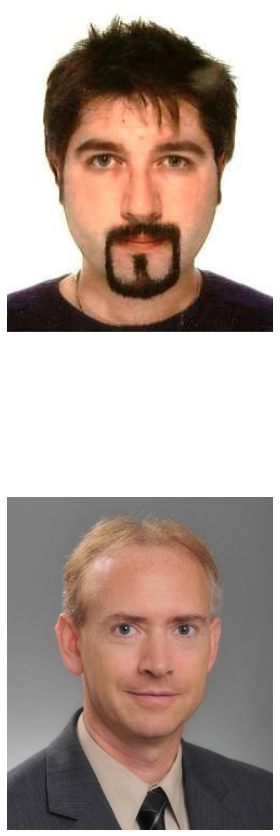

E-mail: harald.katzmair@fas.at
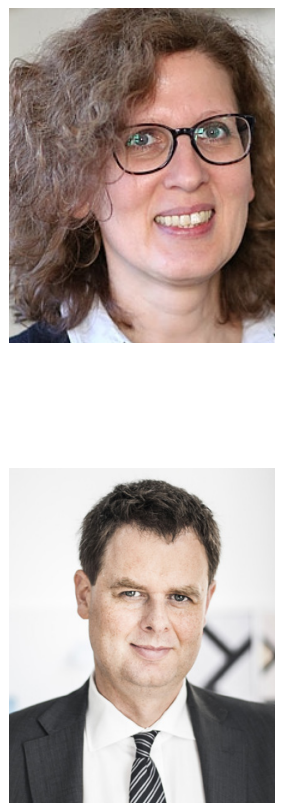
Michael Thompson studied anthropology, while also following a career as a Himalayan mountaineer (Annapurna South Face 1970, Everest Southwest Face 1975). His early research on how something second-hand becomes an antique, or a rat-infested slum part of Our Glorious Heritage ("Rubbish Theory", 1979, Oxford University Press; new and extended edition, 2017, Pluto Press) diverted him into teaching at the Slade School of Fine Art, in London, and at Portsmouth University's School of Architecture, and from there to the International Institute for Applied Systems Analysis, Laxenburg, Austria. There he has worked on energy futures, on risk perception, on participatory processes and on environment and development in the Himalayan Region, the key unifying concept in all that being "plural rationality": people doing very different things and yet still behaving rationally, given their different sets of convictions as to how the world is and people are.

E-mail: thompson@iiasa.ac.at

Verena Winiwarter is Professor of Environmental History at Alpen-AdriaUniversität Klagenfurt since 2007. First trained as a chemical engineer, she holds a $\mathrm{PhD}$ in Environmental History from Vienna University, where she was granted the venia legendi in Human Ecology in 2003. Her research interests comprise the history of rivers, landscapes, tourism and its images, and the environmental history of soils. She led two interdisciplinary projects to reconstruct the Danube and the smaller Viennese Rivers and trace their history over more than 450 years and one to study the evolution of Alpine Ski Tourism in Austria. A full member of the Austrian Academy of Sciences, she has published numerous articles and edited several books. In 2014, she was Austrian Scientist of the Year, her popular "Umwelt hat Geschichte. 6o Reisen durch die Zeit" (2014) was elected 'Umweltbuch des Jahres' in Germany. For her current sabbatical (3-9/2017), she has joined IIASA's Risk and Resilience Program to bring environmental history and risk research into contact. E-mail:Verena.Winiwarter@aau.at
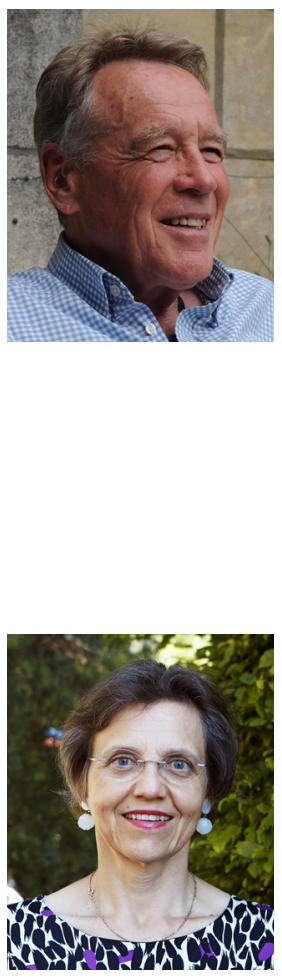